\title{
A Nonlinear Numerical Model and its Utilization in Simulating the In-Plane Behaviour of Multi-Story R/C frames with Masonry Infills
}

\author{
G.C. Manos*, V. J. Soulis and J. Thauampteh \\ Department of Civil Engineering, Aristotle University of Thessaloniki, Thessaloniki, Greece
}

\begin{abstract}
This paper presents first a valid, fully non-linear 2-D numerical model that can capture realistically the in-plane hysteretic behaviour of reinforced concrete (R/C) frames with masonry infills when they are subjected to combined vertical and cyclic horizontal loads in order to predict their post-elastic earthquake bahaviour. The effectiveness of this simulation was validated by comparing the numerically predicted behaviour with results from a series of pseudo-dynamic tests whereby a number of 1:3 scale, one-bay, one-story R/C frame specimens, including relatively weak masonry infills, were subjected to combined vertical and cyclic horizontal seismic-type loads. The role of the interface between the masonry infills and the surrounding concrete frame was also included in this simulation. Next, this paper deals with the applicability of this successful non-linear masonry-infill concrete-frame numerical simulation to predict realistically the seismic behaviour of prototype multi-story R/C frame structural formations with masonry infills. The major obstacle here is the computational time and memory requirements needed for the completion of such a numerical analysis including all the nonlinear mechanisms which were employed in the preceding simulation of the single-story one-bay R/C frame with masonry infills. In order to overcome this obstacle, use was made of an equivalent post-elastic "pushover" type of analysis that draws information on the stiffness and strength variation from one-bay, one-story R/C masonry infilled unit frames that compose a given multistory structural formation. In doing so, the fully non-linear numerical simulation of the single-story units that compose this structural formation, presented in the first part, is utilized.
\end{abstract}

Keywords: Numerical simulation, Masonry-infilled R/C frames, Equivalent step-by-step elastic analysis for buildings.

\section{INTRODUCTION}

Many researchers in the past have attempted validations of numerical simulations of the non-linear behaviour of unreinforced masonry similar to what is tried here, employing non-commercial or commercial software [1]. Da Porto, Guidi, Garbin, Modena [2] carried out an extensive experimental program employing small masonry assemblages and subjecting them to uni-axial and diagonal compression tests as well as in-plane cyclic shear-compression tests, aimed at defining the in-plane cyclic behaviour of three types of load bearing masonry walls assembled with perforated clay units and various types of head and bed joints.

Significant research effort has also been devoted to the analysis of masonry infilled frames utilizing the finite element method. Dhanasekar and Page 1986 [3], developed an iterative non-linear finite element model incorporating a biaxial strength envelope for the infill and one-dimensional joint element to model the interface between infill and surrounding frame. Zarnic 1995 [4], proposed two models, one for the simulation of the inelastic response to monotonous loading and the other for the simulation of the inelastic response to dynamic loading. These two models are based on experimental and analytical research involving 34 one-bay one-story models. The first model can be used for the quick

*Address correspondence to this author at the Department of Civil Engineering, Aristotle University of Thessaloniki, Thessaloniki, Greece; Tel: 00302310 995653: Fax:0030 2310995769 ;

E-mail: gcmanos@civil.auth.gr judgment of the stiffness and the load-bearing capacity of infilled frames; it assumes a tri-linear relationship between deformation and base shear. The second model, which is incorporated in a computer program for dynamic analysis, includes frame elements, which are modelled as flexural springs, and masonry infills, which are modelled as pairs of compressive longitudinal springs. Zarnic, Selih, Damjanic and Gostic 1995 [5], developed a two-dimensional planestress finite element model for un-reinforced and reinforced masonry infill using a Drucker-Prager type yield surface. The behaviour of reinforcement for the frame is idealised using a uni-axial elastoplastic model resisting only axial forces whereas the contact between the frame and the masonry infill is modelled with a $10 \mathrm{~mm}$ thick interface layer. Singh, Paul and Sastry 1997 [6], presented an inelastic finite element model to simulate the entire time history response of reinforced concrete masonry infilled frames. This inelastic model is capable of predicting the sequence of the formation of plastic hinges in the surrounding frame as well as that of cracks in the infills. Gosh and Amde 2002 [7], proposed a finite element simulation to study the failure modes of infilled frames employing a variety of different frame-infill strengths, as described by the analytical methods of previous investigators (Riddington 1984 [8], Pook and Dawe 1986 [9]). They compared their predictions with the experimental results of previous researchers and they proposed two failure criteria for the masonry infill; the first includes a homogenisation approach together with the Von Mises criterion for plane stress condition and a smeared crack model, whereas in the second approach the mortar joints of the masonry infill are modelled assuming a combination of the Mohr-Coulomb 
yield criterion together with a yield criterion in tension. Asteris [10] investigated the use of micro-modelling in predicting the behaviour of infilled frames whereas Manos et al. [11] validated a micro-modelling as well as a macromodelling numerical approach capable of capturing the behaviour of masonry assemblages and masonry-infilled $\mathrm{R} / \mathrm{C}$ frames subjected to combined vertical and cyclic horizontal seismic-type loading.

Stylianides 1985 [12, 13], conducted an extensive experimental program with sixteen single-story one bay $1 / 3$ scaled masonry infilled R/C frame models. These specimens are used here for the validation of the numerical model proposed in this study. The influence of the important parameter concerning the level of interaction between the masonry infill and the surrounding $\mathrm{R} / \mathrm{C}$ frame is also looked at by Stylianides [12]. Carydis et al. [14] also pointed out the significant influence on the observed behaviour of masonry infills exercised by the gap $(0,5 \mathrm{~cm}$ to $1 \mathrm{~cm})$ between the masonry infill and the surrounding $\mathrm{R} / \mathrm{C}$ frame which resulted from shrinkage during the construction period of the masonry infill. Valiasis [15] studied additionally the influence of axial load on the columns of the surrounding R/C frames, the length over height ratio of infilled $\mathrm{R} / \mathrm{C}$ frames, the reinforcement ratio and the thickness of the infill masonry panels.

In the first part of the current study, presented in section 2, a macro-modeling technique for the numerical simulation of masonry infill panels is adopted. Prior to simulating the behaviour of these masonry infill panels, this technique was validated with experimental results obtained either from diagonal compression tests on square masonry panels or from racking tests with masonry piers (Manos et al. [11], Thauampteh [16]. Both the square masonry panels, tested under diagonal compression, and the masonry piers, tested under simultaneously vertical compression and horizontal racking cyclic forces, had the same mechanical characteristics as the masonry infills used for the construction of masonry-infilled $\mathrm{R} / \mathrm{C}$ frames that are included in this paper (Thauampteh, [16]) and Manos et al. [17]). The experimental results from these tests compare reasonably well with the predictions from the numerical simulation. This provided the necessary confidence that the proposed numerical simulation can successfully capture the non-linear behaviour of masonry-infilled R/C frames. In this effort the same macromodel validated before is selected to be used in the numerical simulation of the masonry infill R/C frame behaviour including stiffness and strength degradation. This is done by numerically simulating the non-linear behaviour of the masonry infill itself, the formation of plastic hinges for the R/C frame at pre-defined locations and the sliding or the separation of the masonry infill from the surrounding $\mathrm{R} / \mathrm{C}$ frame.

A number of single-story one-bay R/C frame scaled specimens with masonry infills were constructed and tested at the strong reaction frame of the Laboratory of Strength of Materials of Aristotle University of Thessaloniki (Thauampteh [16]). The emphasis in the first part of this paper, presented in section 2, is to employ the proposed numerical simulation for approximating the observed in-plane cyclic response of masonry infilled $\mathrm{R} / \mathrm{C}$ specimens from this experimental sequence [16] as well as of the experimental se- quences conducted by Stylianides [12]. The validation of the proposed numerical approach was done through: a) the comparison between the numerical and experimental cyclic response of the infilled $\mathrm{R} / \mathrm{C}$ frames under the combination of vertical cyclic horizontal loads, b) the comparison of the damage patterns predicted numerically and observed experimentally, c) the comparison of the shear behaviour of masonry infills themselves, assuming different interface and levels of interaction between the infills and the surrounding $\mathrm{R} / \mathrm{C}$ frame.

The significance of the out-of-plane behaviour of the masonry infills is pointed out by Carydis et. al [14], as is also seen from damage observations after strong earthquake events. However, in all these studies as well as in the present investigation only the in-plane behaviour is examined. Moreover, the possibility of the R/C structural elements developing shear mode of failure should also be investigated, as such a mode of failure is, in many practical cases, a realistic possibility. This is being currently investigated; however, it can not be easily validated due to lack of available experimental data. Consequently, all the examined R/C infilled frames were numerically simulated without the capability of developing shear mode of failure on their $\mathrm{R} / \mathrm{C}$ structural members. As the validation of the proposed numerical simulation was performed by Soulis [18] directly with the results obtained from the $1 / 3$ scaled specimens tested by either Stylianides [12] or Thauampteh [16], any influences arising from scaling were ignored. It is expected that such influences cannot be significant as the used masonry infills were constructed with prototype burnt clay units together with prototype mortar mixes and mortar joints that were approximately $9 \mathrm{~mm}$ to $10 \mathrm{~mm}$ thick, which is close to the thickness of prototype mortar joints. This type of weak masonry employed as masonry infill was dominated by the compression-shear (frictional) non-linear mechanism that developed at these joints.

Soulis [18], also studied the capability of the proposed numerical simulation of capturing the experimental behaviour of multi-story 2-D frames. The numerical simulation proposed in the first part was used to simulate the behaviour of such three-story structural formations including masonry infills; in particular a multi-story planar R/C frame structure, that was constructed and tested at the University of California, Berkeley by Klingner and Bertero [19] was examined. Reasonably good agreement was observed between the numerical results and the experimental measurements regarding the hysteretic behaviour of the "bare", and infilled threestory specimens. Next, a "pushover" analysis was performed for a planar 6-story infilled RC building. This analysis was accomplished to a satisfactory degree despite the significant number of finite elements utilized in the numerical simulation and the high computational requirements. In order to overcome this difficulty a new equivalent analysis is proposed and validated, aiming to incorporate the influence of the masonry infills for multi-story structural formations. For this purpose, the previously mentioned planar 6-story structural formation is selected for the validation of the proposed equivalent method of analysis. More specifically, as will be described in section 3 of this paper, the masonry infills of this planar 6-story, R/C structure are modeled as diagonal strut members as proposed by Holmes [20, 21]; however, 
these are modeled with multi-linear properties. The numerical response obtained from a "pushover" analysis employing these "multi-linear" diagonal struts is compared with the corresponding predictions employing the fully non-linear approach presented in the first part of this paper.

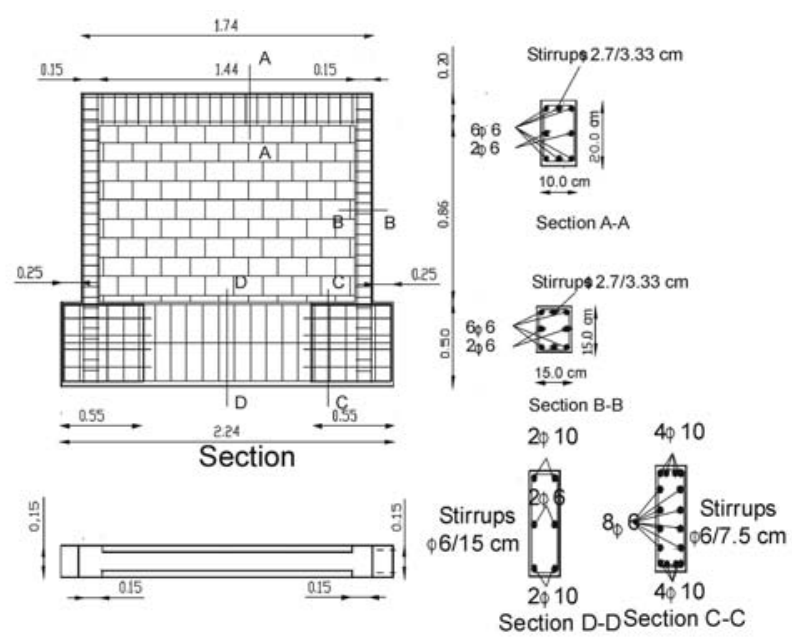

Plan view

Fig. (1). Masonry infilled R/C frame $1^{\text {st }}$ specimen and design details [12].

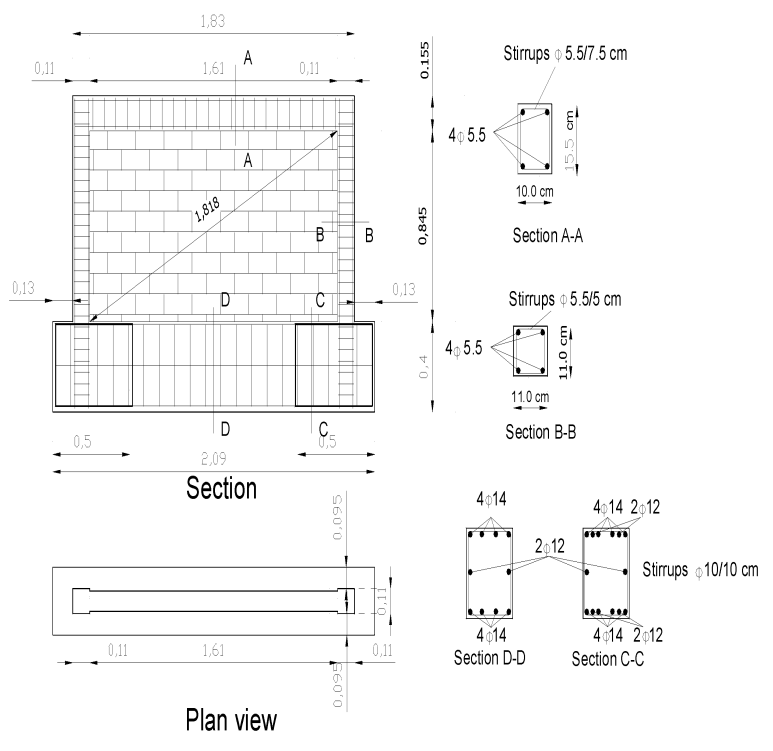

Fig. (2). Masonry infilled R/C frame $2^{\text {nd }}$ specimen and design details [16].

\section{NUMERICAL SIMULATION OF THE BEHAVIOUR OF MASONRY-INFILLED R/C FRAMES SUBJECTED TO CYCLIC HORIZONTAL AND VERTICAL IN- PLANE LOADS}

A series of reinforced concrete infilled frames were subjected to cyclic horizontal loading during the experimental investigation that took place in the Laboratory of Strength of Materials of the University of Thessaloniki $([16,17])$. The first group of one-bay one-story frames were 1/3 scaled models with height over length ratio equal to $1.5(1 / \mathrm{h}=1.5)$.
The cross-section of the columns was $150 \mathrm{mmx} 150 \mathrm{~mm}$ and that of the beam $100 \mathrm{~mm} \times 200 \mathrm{mmm}$ and reinforcement ratio equal to $0.01(\rho=1 \%)$. An axial load level of $80 \mathrm{KN}$ was applied at the top of each column by a hydraulic actuator. This was kept constant during the cyclic horizontal loading. Lateral load was applied by placing two single hydraulic actuators at the level of the horizontal axis of the $\mathrm{R} / \mathrm{C}$ beam. Two types of masonry panels were employed for the construction of the masonry infilled R/C frames. One was constructed with mortar type $\mathrm{O}$ (relatively weak) and the other with mortar type S (relatively strong). The thickness of the masonry infills was $63 \mathrm{~mm}$. The wedging condition of the masonry infill within the frame was studied by testing either a specimen with a $1 \mathrm{~mm}$ gap between the infill and the beam or of a specimen where the masonry infill was built in contact with the columns without this gap. These specimens were ten weeks old when tested. A brief description of the $1^{\text {st }}$ group of specimens is provided in Table 1, while Fig. (1) presents structural details of a typical frame of the $1^{\text {st }}$ group of specimens. These frames are designated with the code names F1N, F2N, F6N. Tables 2 and $\mathbf{3}$ list the mechanical properties of the materials used in the construction of these $\mathrm{R} / \mathrm{C}$ masonry infilled frames.

The second group of one-bay one-story frames was also subjected to cyclic horizontal loading during the experimental investigation that took place in the Laboratory of Strength of Materials and Structures of the University of Thessaloniki (Thauampteh [16]). This group of specimens include onebay one-story $1 / 3$-scale models with overall external dimensions $1720 \mathrm{~mm}$ (length) x $1000 \mathrm{~mm}$ (height) and a length over height ratio equal to $1.7(1 / \mathrm{h}=1.7$, Fig. 2). The cross-section of the columns was $110 \mathrm{mmx} 110 \mathrm{~mm}$ and that of the beam $100 \mathrm{~mm} \times 155 \mathrm{mmm}$. The reinforcement ratio was equal to $0.00785(\rho=0.785 \%)$. Axial load equal to $50 \mathrm{KN}$ was applied at the top of each column by a hydraulic actuator. This was also kept constant during the cyclic horizontal loading.

The results of the full study are included in the work by Thauampteh [16], where the behaviour of ten "bare" and masonry infilled specimens is examined in detail. Moreover, the extensive comparison of various numerical simulations with the behaviour observed by Thauampteh [16], as well as by Stylianides [12], Valiasis [15], and Yasin [22] for the masonry infilled $\mathrm{R} / \mathrm{C}$ frames is included in the work by Soulis [18] where the conclusions of the corresponding extensive validation, utilizing the results of all these experimental studies $[12,15,18,22]$ are also presented. Finally, a summary of the most important conclusions of this validation between the proposed numerical simulation of the masonry is presented in a recent publication of Manos et al. [11]. Due to space limitations, the validation of the proposed numerical simulations presented here is limited to the masonry infills utilising only three specimens investigated by Thauampteh [16] as well as three specimens investigated by Stylianides [12]. The specimens examined by Thauampteh [16] are the ones designated with the code names F3N(R1f,0w)s, F3N(R1f,0w)*s, F3N(R1f,R1w)s. Brief information on the selected masonry infilled $\mathrm{R} / \mathrm{C}$ specimens together with the experimental arrangement and the loading sequence is listed in Table $\mathbf{1}$ and depicted by Figs. (2) and (3a,b,c,d,e). 
Table 1. Outline of all Specimens for the $1^{\text {st }}$ and $2^{\text {nd }}$ Group of Specimens

\begin{tabular}{|c|c|c|c|c|c|}
\hline $\begin{array}{c}\text { Frame } \\
\text { Code name }\end{array}$ & $\begin{array}{c}\text { Length over Height } \\
\text { ratio }\end{array}$ & $\begin{array}{l}\text { Vertical load on Col- } \\
\text { umns (KN) }\end{array}$ & $\begin{array}{l}\text { Technical description } \\
\text { of masonry infill }\end{array}$ & $\begin{array}{l}\text { Masonry Infill } \\
\text { thickness (mm) }\end{array}$ & $\begin{array}{l}\text { Technical description } \\
\text { of the interface be- } \\
\text { tween frame and infill }\end{array}$ \\
\hline F1N [12] & 1,5 & 80 & $\operatorname{mortar} \mathbf{S}$ & 63 & $\begin{array}{l}\text { mortar } \mathbf{S} \text { thickness } \\
\mathbf{1 0} \mathbf{m m} \text { (without plaster) }\end{array}$ \\
\hline F6N [12] & 1.5 & 80 & $\operatorname{mortar} \mathbf{O}$ & 63 & $1 \mathrm{~mm}$ gap \\
\hline \multicolumn{6}{|c|}{$2^{\text {nd }}$ group of specimens } \\
\hline $\begin{array}{l}\text { F3N(R1f,0w)s } \\
\text { (Repaired) [16] }\end{array}$ & 1.7 & 50 & mortar V1 & 58.5 & $\begin{array}{l}\text { mortar } \mathbf{H} \text { thickness } \\
\mathbf{1 0} \mathbf{m m} \text { (without plaster) }\end{array}$ \\
\hline $\begin{array}{l}\text { F3N(R1f,R1w)s } \\
\text { (Repaired) [16] }\end{array}$ & 1.7 & 50 & $\begin{array}{l}\text { Infill with mortar V1, } \\
\text { reinforced with rein- } \\
\text { forced plaster, and } \\
\text { transverse reinforce- } \\
\text { ment type } \mathbf{I}\end{array}$ & 78.5 & $\begin{array}{l}\text { mortar } \mathbf{H} \text { thickness } \\
\mathbf{1 5} \mathbf{m m} \text {. The reinforced } \\
\text { plaster is not in contact } \\
\text { with the surrounding } \\
\text { frame }\end{array}$ \\
\hline
\end{tabular}

$\mathrm{F} 3 \mathrm{~N}(\mathrm{R} 1 \mathrm{f}, 0 \mathrm{w}) * \mathrm{~s}$ is the same as specimen $\mathrm{F} 3 \mathrm{~N}(\mathrm{R} 1 \mathrm{f}, 0 \mathrm{w}) \mathrm{s}$ but having $15 \mathrm{~mm}$ interface between frame and infill.

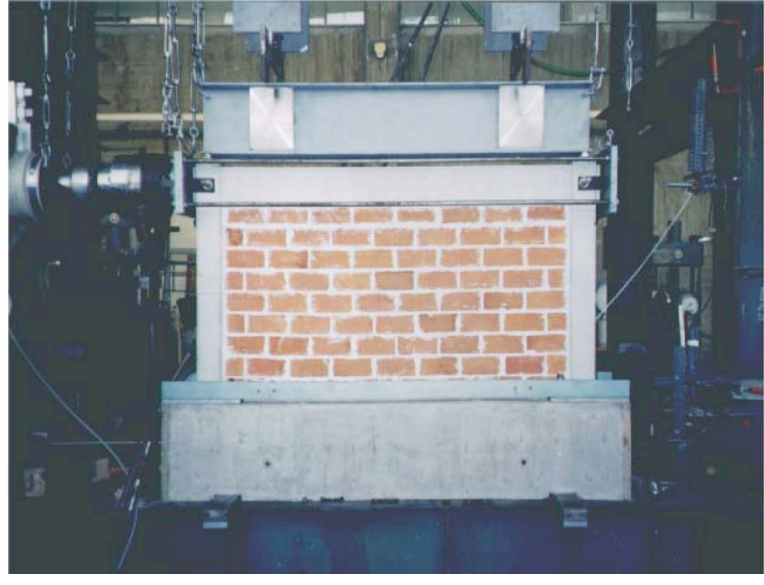

a) Test specimen [16]

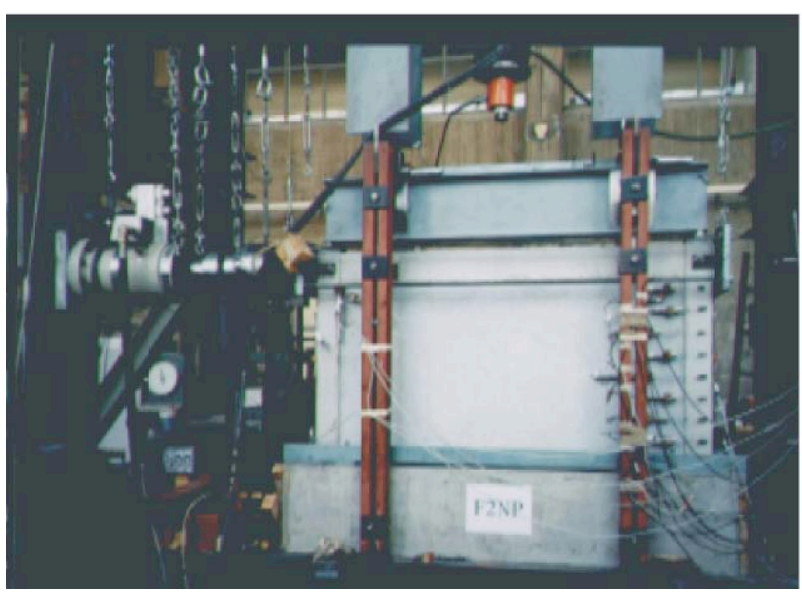

b) Test specimen [16]

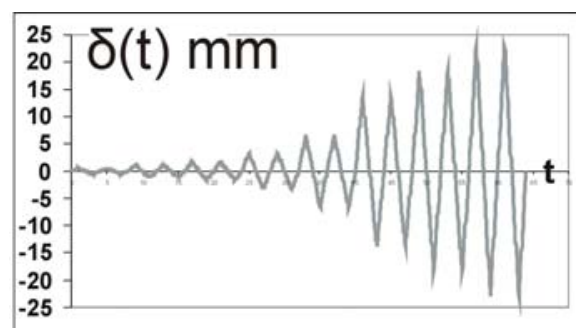

c) Loading sequence [12]

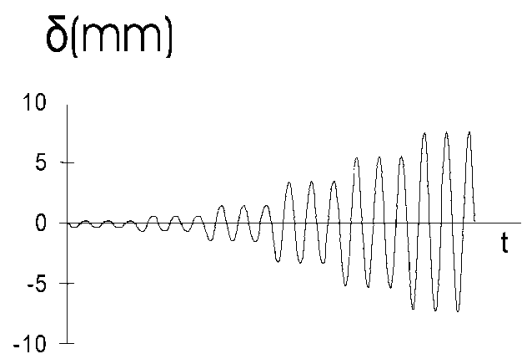

d) Loading sequence [16]

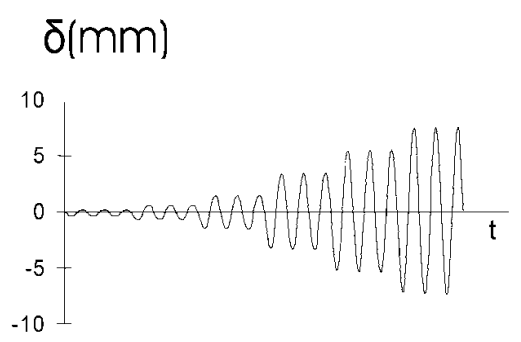

e) Loading sequence [16]

Fig. (3). (a) Test set up of frame with repaired masonry infill F3N(R1f,0w)s, b)Test set up of frame whereby the masonry infill had both its faces covered with reinforced plaster( F3N(R1f,R1w)s, c) Loading sequence for frames F1N, F2N, F6N d) Loading sequence for frame $\mathrm{F} 3 \mathrm{~N}(\mathrm{R} 1 \mathrm{f}, 0 \mathrm{w}) \mathrm{s}$, e) Loading sequence for frame $\mathrm{F} 3 \mathrm{~N}(\mathrm{R} 1 \mathrm{f}, \mathrm{R} 1 \mathrm{w}) \mathrm{s}$. 
Table 2. Strengths of Masonry Infills and Concrete for the $1^{\text {st }}$ and $2^{\text {nd }}$ Group of Specimens

\begin{tabular}{|c|c|c|c|c|c|c|}
\hline Masonry infill & $\begin{array}{l}\text { Masonry Infill } \\
\text { thickness (mm) }\end{array}$ & $\begin{array}{l}\text { Compressive } \\
\text { strength of ma- } \\
\text { sonry }\left(\mathrm{N} / \mathrm{mm}^{2}\right)\end{array}$ & $\begin{array}{l}\text { Shear strength of } \\
\text { masonry under } \\
\text { diagonal com- } \\
\text { pression }\left(\mathrm{N} / \mathrm{mm}^{2}\right)\end{array}$ & $\begin{array}{l}\text { Compressive } \\
\text { strength of ma- } \\
\text { sonry units } \\
\left(\mathrm{N} / \mathrm{mm}^{2}\right)\end{array}$ & $\begin{array}{l}\text { Compressive } \\
\text { strength of con- } \\
\text { crete }\left(\mathrm{N} / \mathbf{m m}^{2}\right)\end{array}$ & $\begin{array}{l}\text { Compressive } \\
\text { strength of mortar } \\
\text { cylinders }\left(\mathrm{N} / \mathrm{mm}^{2}\right)\end{array}$ \\
\hline $\mathrm{O}$ & 63 & 1.86 & 0.26 & 5.96 & 27.9 & 2.4 \\
\hline \multicolumn{7}{|c|}{$2^{\text {nd }}$ group of specimens Virgin infill [16] } \\
\hline V1 & 58,5 & 2,765 & 0.180 & 6.50 & 25.9 & 1.125 \\
\hline \multicolumn{7}{|c|}{$2^{\text {nd }}$ group of specimens Reinforced infill } \\
\hline $\begin{array}{l}\text { Infill with mortar } \\
\text { V1, reinforced } \\
\text { with reinforced } \\
\text { plaster }\end{array}$ & 78,5 & 3,75 & 0.44 & 6.50 & 25.9 & 1.125 \\
\hline
\end{tabular}

Table 3. Tensile Strength of the Reinforcement used in $1^{\text {st }}$ and $2^{\text {nd }}$ Group of Specimens $[12,16]$

\begin{tabular}{|c|c|c|c|c|c|}
\hline $\mathbf{A} / \boldsymbol{\alpha}$ & $\begin{array}{l}\text { Yield stress } \\
\mathbf{f}_{\mathrm{sy}}\left(\mathrm{N} / \mathbf{m m}^{2}\right)\end{array}$ & $\begin{array}{l}\text { Ultimate strength } \\
\mathbf{f}_{\mathrm{su}}\left(\mathrm{N} / \mathbf{m m}^{2}\right)\end{array}$ & Strain at yield $\varepsilon_{\mathrm{sy}}(\%)$ & $\begin{array}{l}\text { Strain at ultimate } \\
\text { stress } \varepsilon_{\mathrm{su}}(\%)\end{array}$ & $\begin{array}{l}\text { Young Modulus } \\
\left(\mathrm{N} / \mathbf{m m}^{2}\right)\end{array}$ \\
\hline Ф5.5 (1 st group) & 311 & 425 & 0.8 & 22.0 & $6.5 \times 10^{4}$ \\
\hline Ф5.5 (1st group) & 360 & 542 & 0.6 & 20.0 & $6.5 \times 10^{4}$ \\
\hline$\Phi 8$ ( $2^{\text {nd }}$ group $)$ & 340.0 & 467.1 & 0.170 & 20.5 & $2.0 \times 10^{5}$ \\
\hline$\Phi 2.7$ ( $2^{\text {nd }}$ group $)$ & 271.0 & 395.0 & 0.135 & 19.0 & $2.0 \times 10^{5}$ \\
\hline
\end{tabular}

As already mentioned, the influence exerted by the interface between the masonry infill and the surrounding frame was examined extensively in both studies by Thauampteh [16] and by Soulis[18]. The validation presented here, although using only the selected specimens is well representative of the most important concluding observations from all these studies where all the relevant results are also included [12, 15, 16, 22]. Tables $\mathbf{2}$ and $\mathbf{3}$ list the mechanical properties of the materials used in the construction of the $1^{\text {st }}$ and $2^{\text {nd }}$ group of specimens.

The cyclic loading was applied gradually through an imposed cyclic horizontal displacement sequence. For the masonry infilled frame specimens F1N, F2N and F6N the loading sequence is depicted in Fig. (3c), employing an eightstep sequence with two load reversals per step. For the masonry infilled frame specimens F3N(R1f,0w)s, F3N(R1f,0w)*s this was done with a six-step sequence (Fig. 3d) employing three full reversals for each step up to the level where the angular distortion for the tested frame reached the value of $8.6 \%$. For the masonry infilled frame specimen F3N(R1f,R1w)s (Fig. 3e), three full load-reversals for each displacement level were employed with a ten-step sequence, up to the level where the angular distortion for the tested frame reached the value of $26.73 \%$.

\subsection{Simulation of the Beam/Column R/C Elements and the Plastic Hinge Formation}

The finite element simulation employed for the $\mathrm{R} / \mathrm{C}$ frame with the masonry infill is shown in Fig. (4). In the numerical model of the surrounding $\mathrm{R} / \mathrm{C}$ frame the beam and the two columns are simulated, together with the locations of possible plastic hinge formation at the ends of each element (Fig. (4) detail No 4 and 5). Thick beam elements, able to deform and rotate in plane, were employed for both the columns and the beam. Rigid beam elements were also employed to simulate the corner connection between the beam and the column (Fig. 4, detail No. 4). A number of nonlinear 2-D joint elements were also employed at the ends of each column (Fig. 4, detail No. 5 and Figs. 5a and 5b). The formation of plastic hinges at each end of the beam is achieved by a number of flexural non-linear 2-D joint elements simulating the flexural moment against the elastic/plastic rotation at this location (Fig. 5, detail No. 4, Figs $\mathbf{6 a}$ and $\mathbf{6 b})$. This time not only the flexural behaviour is simulated, by the moment versus the elastic/plastic rotation (with the presence of axial load) relationship, but also the slip of the reinforcement. These non-linear 2-D joint elements are also represented in Fig. (5b) by the " $z$ " symbol. The measured mechanical properties of the concrete and 


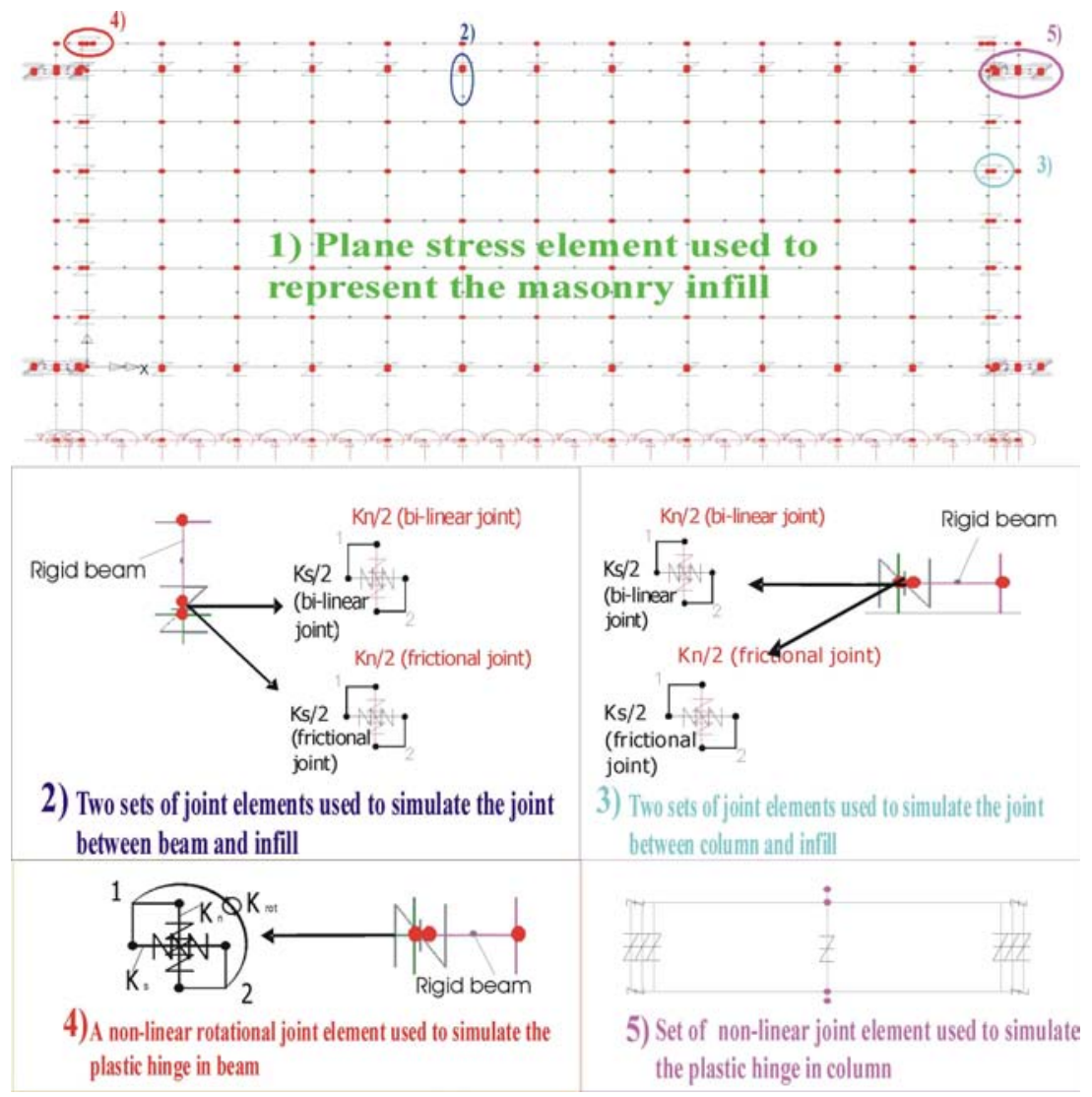

Fig. (4). Finite element simulation of masonry infilled R/C model.

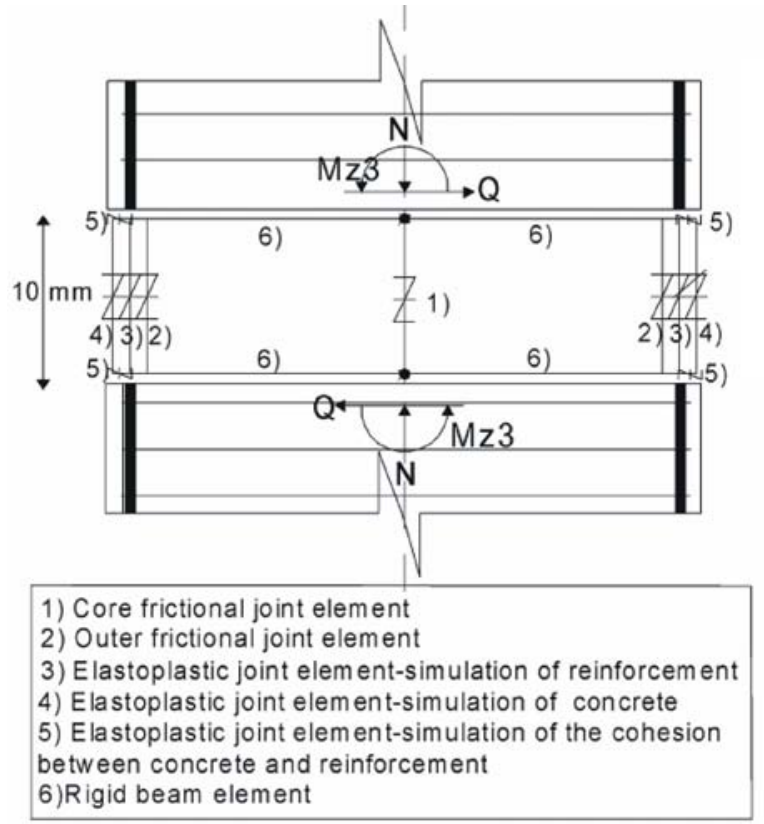

a)

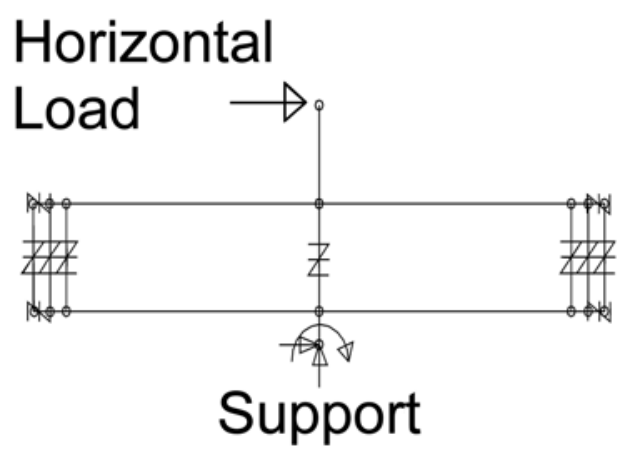

b)

Fig. (5). (a) Cross section of column with the reinforcement and the simulation of plastic hinge, b) Combination of joint elements used in LUSAS software [1] for the estimation of Moment-Rotation curve for column cross section.

reinforcement for the tested specimens are utilized to obtain the necessary values for the properties of these non-linear 2$D$ joint elements.

In Fig. (7a) moment-rotation relationship for the beam cross-section, the calculated by a specialized software
(RCCOLA [23]) and based on its particular detailing and material properties, is compared with the corresponding behaviour produced by this non-linear 2-D joint element simulation. Similar comparison is made in Fig. (7b) for the column cross-section with the axial load level equal to $50 \mathrm{KN}$; 


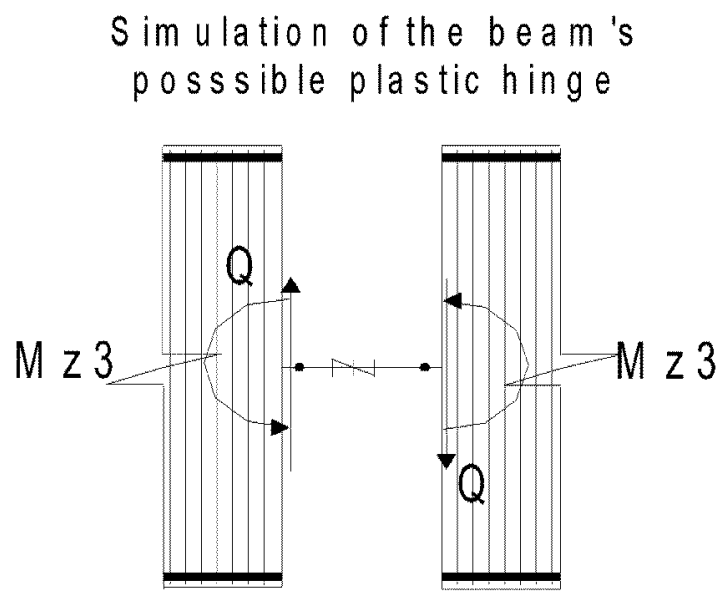

a)

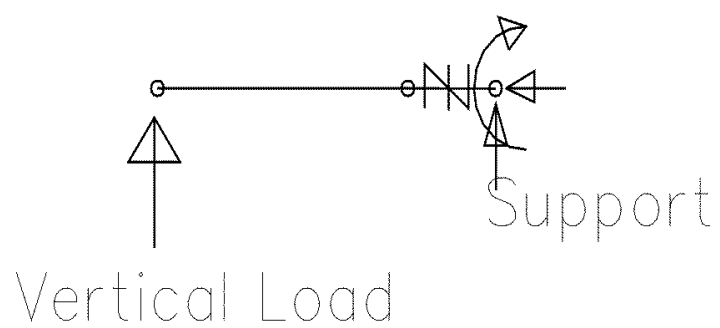

b)

Fig. (6a). (a) Cross section of beam with the reinforcement and the simulation of plastic hinge, b) Rotational joint element used in LUSAS software [1] for the estimation of Moment-Rotation curve for beam cross section.

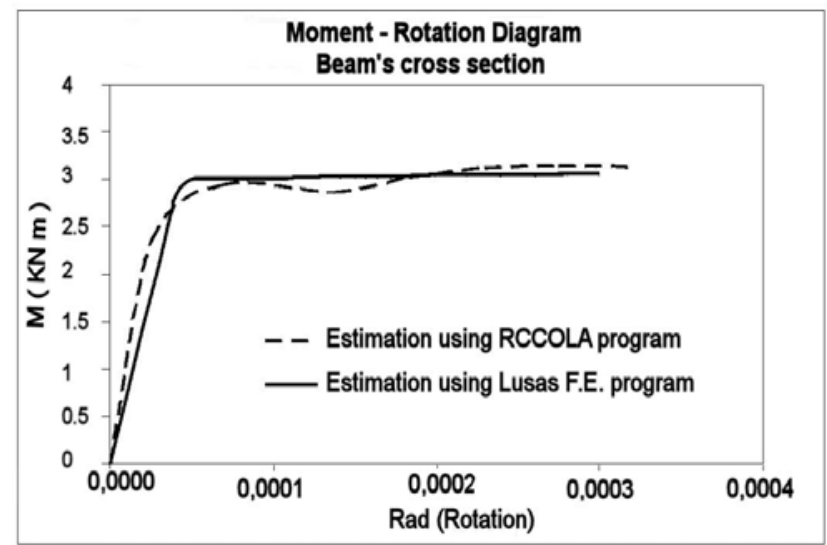

a)

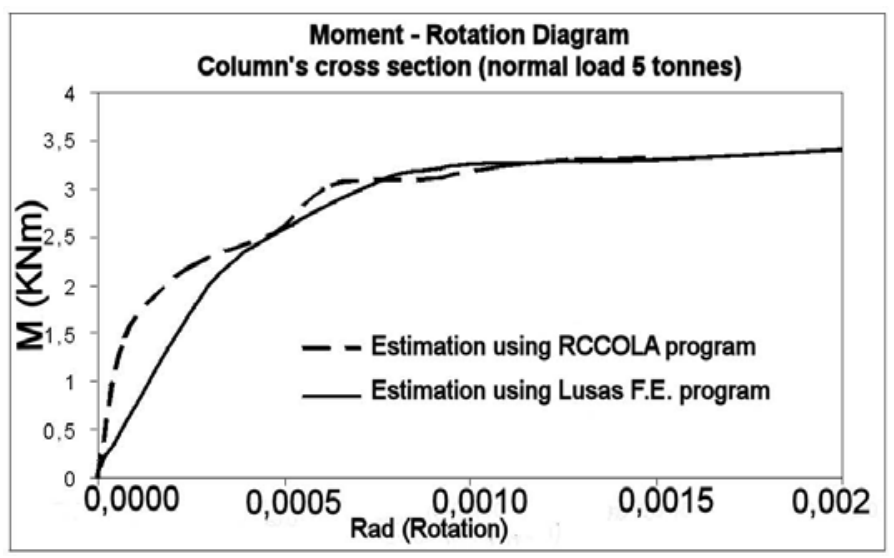

b)

Fig. (7). (a) Moment-Rotation curve for beam cross section, b) Moment-Rotation curve for Column cross section.

this axial load level was employed for all the R/C masonry infilled specimens of the $2^{\text {nd }}$ group. As can be seen, these non-linear 2-D joint elements successfully simulate the flexural moment - elastic/plastic rotation, calculated by means of a specialised software (RCCOLA [23]). Thus, they are expected to simulate in a realistic way the non-linear flexural behaviour of the critical sections of the examined reinforced concrete frame elements.

\subsection{Simulation of the Masonry Infill}

Plane stress elements are used for simulating the masonry infill (Fig. 4 detail No 1); they are connected to the surrounding frame by a different series of 2-D joint elements that simulate the masonry infill to $\mathrm{R} / \mathrm{C}$ frame interface (peripheral mortar joint), as described below. The selection of size of these plane stress elements was decided in a way that minimizes the computational cost but attains a satisfactory degree of accuracy for the simulation of the masonry infill behaviour. It is assumed that a single material law including an isotropic modified Von Mises failure criterion governs the behaviour of the masonry infill. The mechanical elastic and post-elastic properties of the different masonry panels that are utilized in this numerical simulation are listed in Table 4.

The initial yield surface assumed in this analysis is shown in Fig. (8). The compressive assumed behaviour is modelled by a stress-strain relationship shown in Fig. (9), which includes a softening branch to simulate masonry crushing. The tensile assumed behaviour upon cracking is modelled by a stress-strain relationship shown in Fig. (10) where a softening branch is also employed. The strength properties and the plastic strain degradation used for the numerical simulation of the masonry infill as indicated by Figs. $(\mathbf{8 , 9}, 10)$ and Table 4 , are based on the corresponding properties used for the successful numerical simulation of the masonry behaviour when subjected to diagonal compression ( Soulis [18]).

\subsection{Simulation of Interface Between the R/C Frame and the Masonry Infill}

The interaction between the $\mathrm{R} / \mathrm{C}$ frame and the masonry infill has a critical role, as it asserts an important influence 
Table 4. Mechanical Properties of Infills Used in the Numerical Simulations

\begin{tabular}{|c|l|l|c|l|l|l|l|}
\hline Test No. & Frame & $\begin{array}{l}\text { E Young } \\
\text { Code name } \\
\left(\mathrm{N} / \mathrm{mm}^{2}\right)\end{array}$ & Poisson ratio & $\begin{array}{l}\mathrm{f}_{\mathrm{k}} \text { Measured } \\
\text { Compressive } \\
\text { strength of } \\
\text { masonry } \\
\left(\mathrm{N} / \mathrm{mm}^{2}\right)\end{array}$ & $\begin{array}{l}\mathrm{f}_{\mathrm{t}} \text { Assumed } \\
\text { Tensile strength } \\
\text { of masonry } \\
\left(\mathrm{N} / \mathrm{mm}^{2}\right) \\
\left(\mathrm{as} \% \text { of } \mathrm{f}_{\mathrm{c}}\right)\end{array}$ & $\begin{array}{l}\mathrm{E}_{\mathrm{sc}} \text { Softening } \\
\text { Modulus under } \\
\text { compression } \\
\left(\mathrm{N} / \mathrm{mm}^{2}\right)\end{array}$ \\
\hline \hline 1 & F1N & 2000 & 0,18 & 3,0 & $0,5(16.7 \%)$ & $-\begin{array}{l}\mathrm{E}_{\mathrm{st}} \text { Softening } \\
\text { Modulus under } \\
\left(\mathrm{N} / \mathrm{mm}^{2}\right)\end{array}$ \\
\hline 2 & F2N & 1500 & 0,18 & 1,80 & $0,30(16.7 \%)$ & -20 & -20 \\
\hline 3 & F6N & 1500 & 0,18 & 1,80 & $0,30(16.7 \%)$ & -20 & -20 \\
\hline 4 & F3N(R1f,0w)s & 1000 & 0.2 & 1.2 & $0.2(16.7 \%)$ & -10 \\
\hline 5 & F3N(R1f,0w)*s & 1000 & 0.2 & 1.2 & $0.2(16.7 \%)$ & -10 \\
\hline 6 & F3N(R1f,R1w)s & 3500 & 0.2 & 4.5 & $0.8(17.7 \%)$ & -10 \\
\hline
\end{tabular}

$\mathrm{F} 3 \mathrm{~N}(\mathrm{R} 1 \mathrm{f}, 0 \mathrm{w})^{*}$ s is the same as specimen $\mathrm{F} 3 \mathrm{~N}(\mathrm{R} 1 \mathrm{f}, 0 \mathrm{w}) \mathrm{s}$ but having $15 \mathrm{~mm}$ interface between frame and infill.

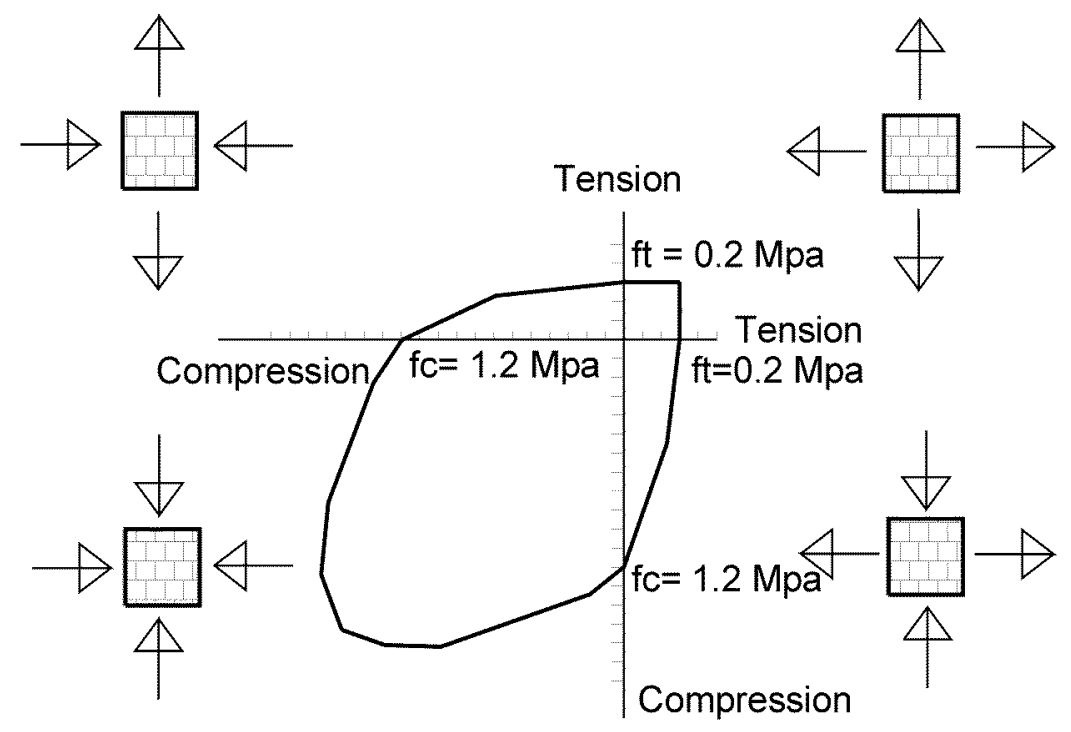

Fig. (8). Failure surface of masonry infill.

\section{Effective stress versus plastic strain for compressive assumed behavior}

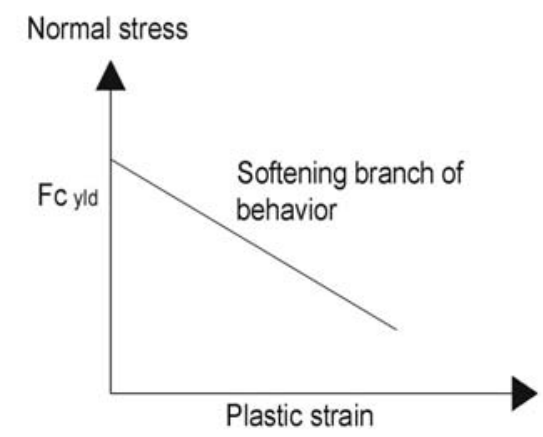

Fig. (9). Effective stress versus plastic strain for compressive assumed behaviour. 


\section{Effective stress versus plastic strain for tensile assumed behavior}

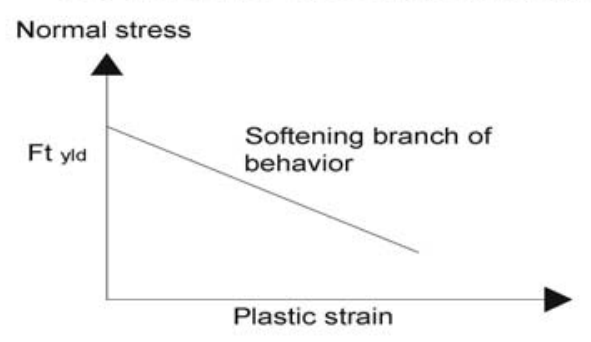

Fig. (10). Effective stress versus plastic strain for tensile assumed behaviour.

Table 5. Mechanical Properties of the Interface used to Simulate the Mortar Joint Between Infill and Surrounding Frame (S, O, $1 \mathrm{~mm}$ gap, H)

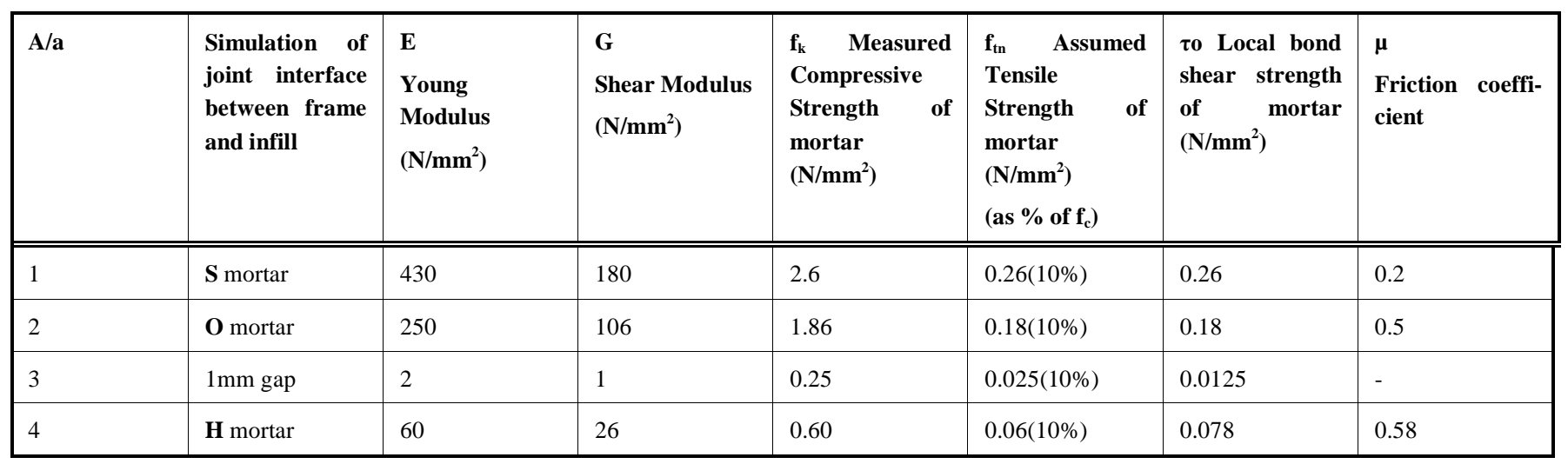

on the resulting state of stress of the masonry infill and contributes to the development of the various masonry failure modes. For this purpose, two sets of non-linear 2-D joint elements are used to simulate the separation and slip between frame and infill as well as the transfer of compression and shear for the three different types of interface. The first set of these 2-D joint elements (Fig. 4 details No 2 and No 3) is active in the direction transverse to the interface; it is of a frictional type, where the value of friction coefficient is introduced (Table 5) which was shown to yield reasonably good behaviour during the numerical simulations of the diagonal compression [18]. The second set of non-linear joint elements (Fig. 4 details No 2 and No 3 ) is active in both the transverse and the normal to the interface directions. In the normal to the interface direction these joint elements have elastic and post-elastic force/displacement properties based on measured compressive strength values listed in Table $\mathbf{5}$ (resulting from the corresponding interface area) together with an assumed post-elastic softening behaviour. Similarly, the elastic and post-elastic force/displacement properties of these joint elements in the transverse direction are based on assumed local bond shear strength with a softening nature (Table 5). Both these two sets of non-linear 2-D joint elements are placed in the perimeter of the masonry infill $-\mathrm{R} / \mathrm{C}$ interface as shown in Fig. (4) by the symbol "z" (Fig. 4 details No 2, and No 3). For the specimens F1N, F2N it is as- sumed that the interface between the frame and the infill is the same with the mortar type used for the construction of the infill panel. The $1 \mathrm{~mm}$ gap in the numerical simulation of F6N frame is simulated, by decreasing substantially the stiffness of the interface used in the numerical simulation of mortar type O. For specimens F3N (R1f,0w)s, F3N (R1f,0w)*s, F3N(R1f,R1w)s, mortar type H was used to simulate the interface (see Table 5). Rigid beam elements were introduced to link the thick beam elements representing the $\mathrm{R} / \mathrm{C}$ frame beam and columns with these non-linear joint elements in this way numerically approximating the interface between masonry infill and $\mathrm{R} / \mathrm{C}$ frame.

\subsection{Validation of the Proposed Numerical Simulation for the Masonry Infilled R/C Frame}

The validation of this proposed numerical simulation of the masonry infill - R/C frame behaviour is presented here by comparing the numerically-predicted with the observed behaviour in terms of: a) load-displacement hysteretic curves, b) shear stress-shear deformation curves of the infill behaviour when different interface is used between the masonry infill and the surrounding frames, c) the damage of the masonry infills.

The comparison of experimental and numerical cyclic response for the masonry infilled R/C frames F1N, F2N, F6N, $\mathrm{F} 3 \mathrm{~N}(\mathrm{R} 1 \mathrm{f}, 0 \mathrm{w}) \mathrm{s}, \mathrm{F} 3 \mathrm{~N}(\mathrm{R} 1 \mathrm{f}, 0 \mathrm{w})^{*} \mathrm{~s}, \mathrm{~F} 3 \mathrm{~N}(\mathrm{R} 1 \mathrm{f}, \mathrm{R} 1 \mathrm{w}) \mathrm{s}$ is depicted 
in Figs. (11) to (16), respectively. The employed numerical simulations predict successfully the strength and loaddisplacement hysteretic behaviour that are observed experimentally for all the examined specimens. This is further discussed in the concluding observations 1 to 6 .

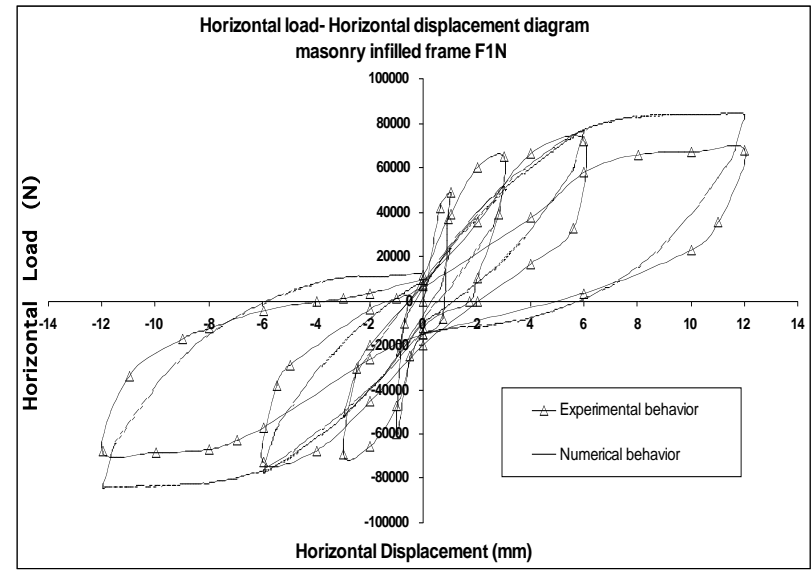

Fig. (11). Comparison of experimental and numerical cyclic response infilled frame F1N.

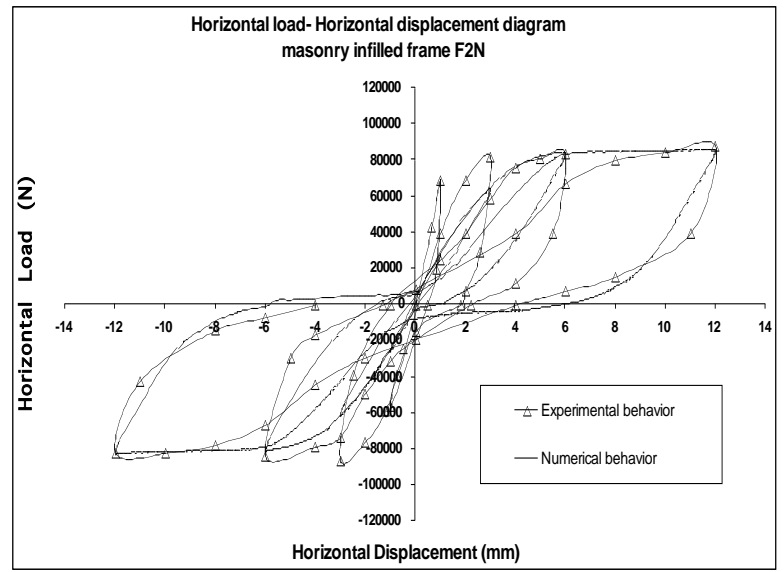

Fig. (12). Comparison of experimental and numerical cyclic response infilled frame F2N.

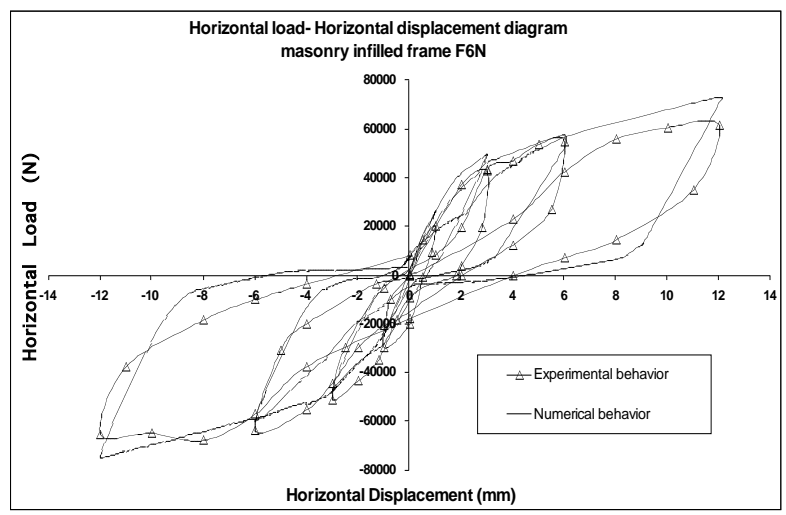

Fig. (13). Comparison of experimental and numerical cyclic response infilled frame F6N.

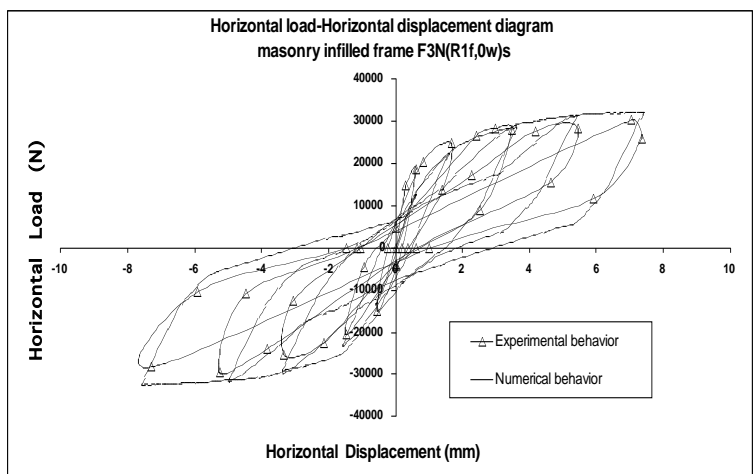

Fig. (14). Comparison of experimental and numerical cyclic response infilled frame $\mathrm{F} 3 \mathrm{~N}(\mathrm{R} 1 \mathrm{f}, 0 \mathrm{w}) \mathrm{s}$.

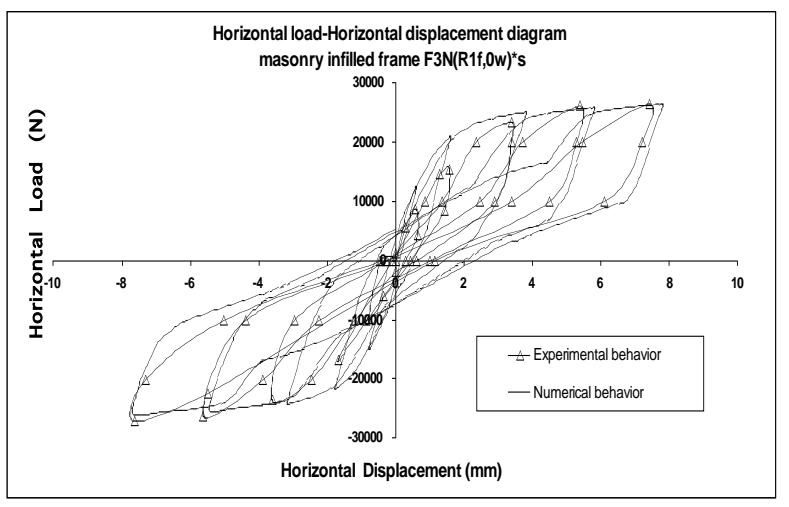

Fig. (15). Comparison of experimental and numerical cyclic response infilled frame F3N(R1f,0w)*s.

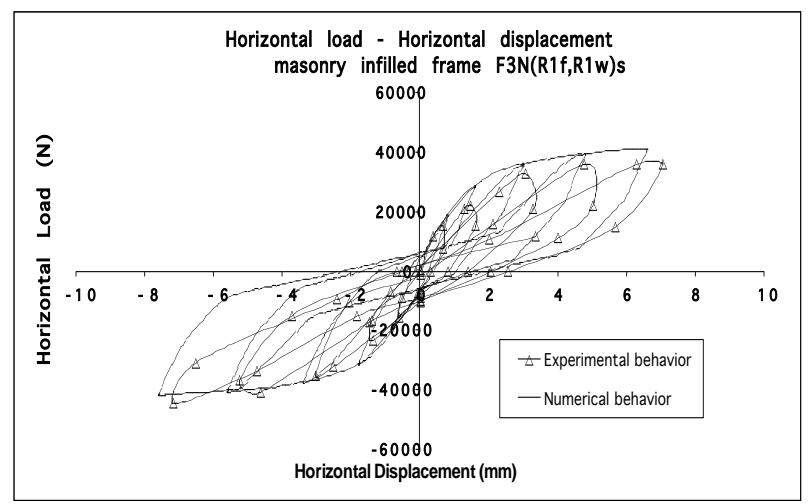

Fig. (16). Comparison of experimental and numerical cyclic response infilled frame $\mathrm{F} 3 \mathrm{~N}(\mathrm{R} 1 \mathrm{f}, \mathrm{R} 1 \mathrm{w}) \mathrm{s}$.

The experimentally-observed and numerically-predicted damage to masonry infill is presented for frames F1N, F2N, F6N, F3N(R1f,0w)s, F3N(R1f,0w)*s, F3N(R1f,R1w)s in the following Figs. (17) to (22). Reasonably good agreement can be seen in these figures. The damage patterns of the masonry infill observed during testing were well approximated by the proposed numerical simulation. The well known damage patterns for relatively weak "Greek" type masonry in the form of either diagonal cracking or compression failure in the regions where the masonry infill corners meet the R/C column to beam joint, are reproduced quite well by the proposed simulation. This is also further discussed in the concluding observations. 


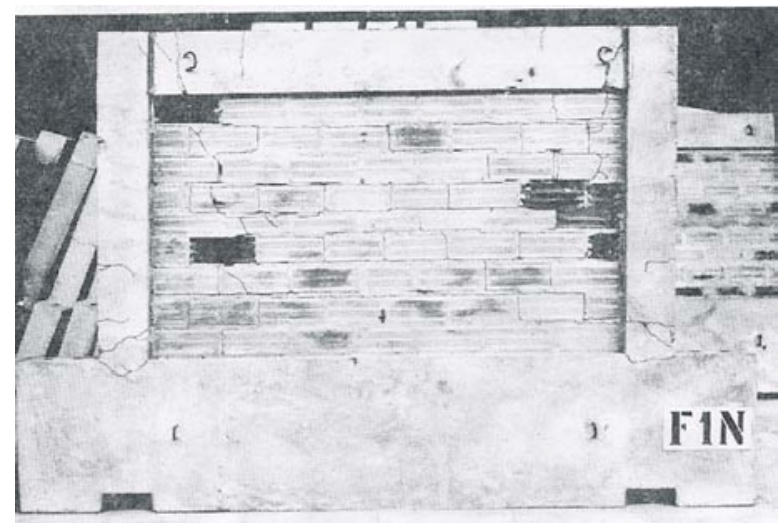

a) Damage pattern [12]

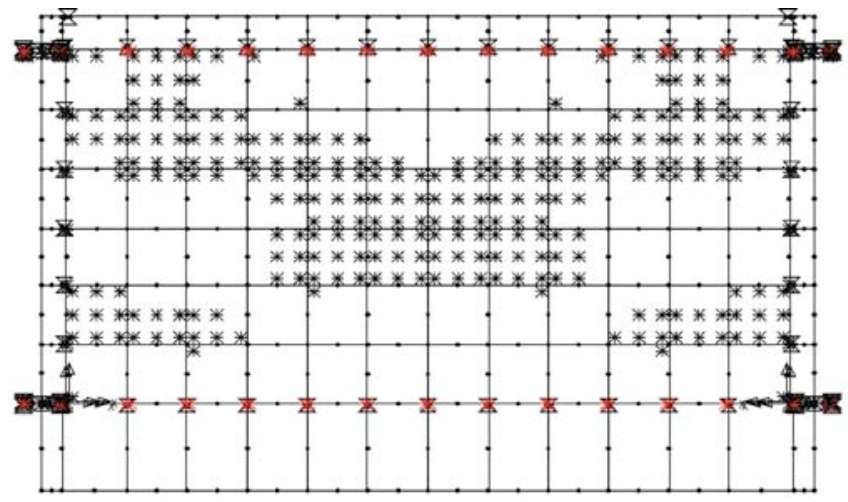

b) Damage pattern [18]

Fig. (17). (a) Damage pattern of masonry infill observed experimentally for infilled frame F1N, b) Damage pattern (x) predicted numerically.

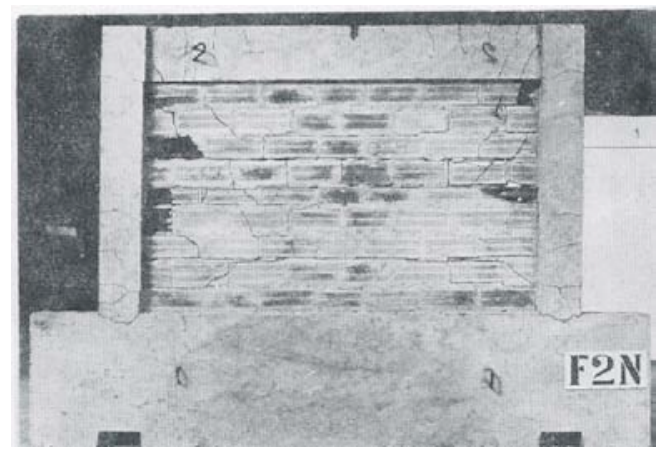

a) Damage pattern [12]

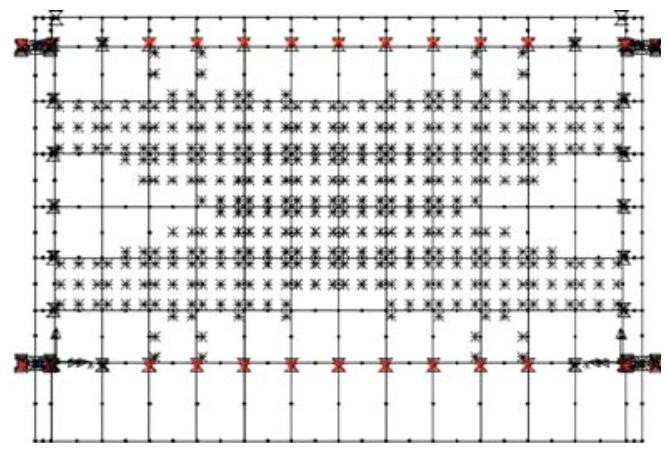

b) Damage pattern [18]

Fig. (18). (a) Damage pattern of masonry infill observed experimentally for infilled frame F2N, b) Damage pattern (x) predicted numerically.

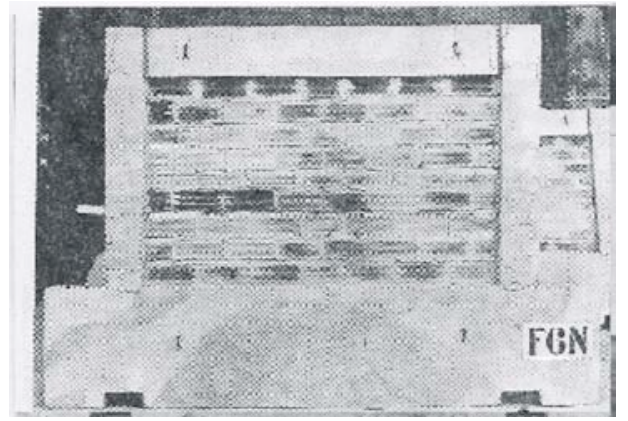

a) Damage pattern [12]

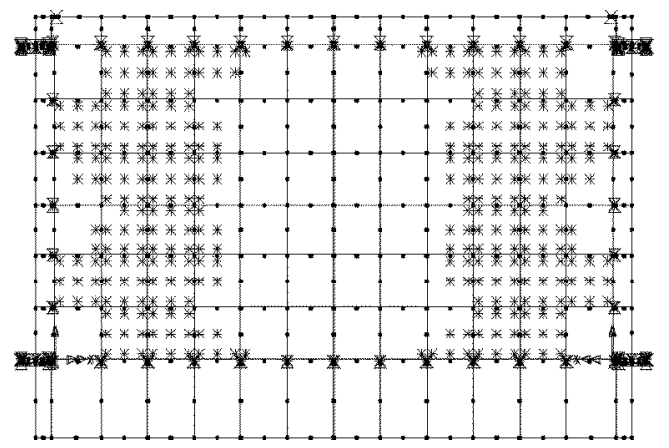

b) Damage pattern [18]

Fig. (19). (a) Damage pattern of masonry infill observed experimentally for infilled frame F6N, b) Damage pattern(x) predicted numerically.

\subsection{Simplification of the Numerical Simulation of the Masonry Infill Frame Response for a Single-Bay One- Story Infilled frame}

In this section, a simplification of the masonry infill frame response for a single-bay one story infilled frame will be examined. This simplification will have the following characteristics:
1. The contact interface of the masonry with the surrounding frame will not be represented in the direct way employed before in section 2.3. As a result, the masonry infill 2-D representation, as outlined in section 2.2, will also be replaced by the well known equivalent diagonal strut model (Fig. 23). On the contrary, all the aspects of the reinforced concrete frame representation, described in section 2.1, will be retained. 


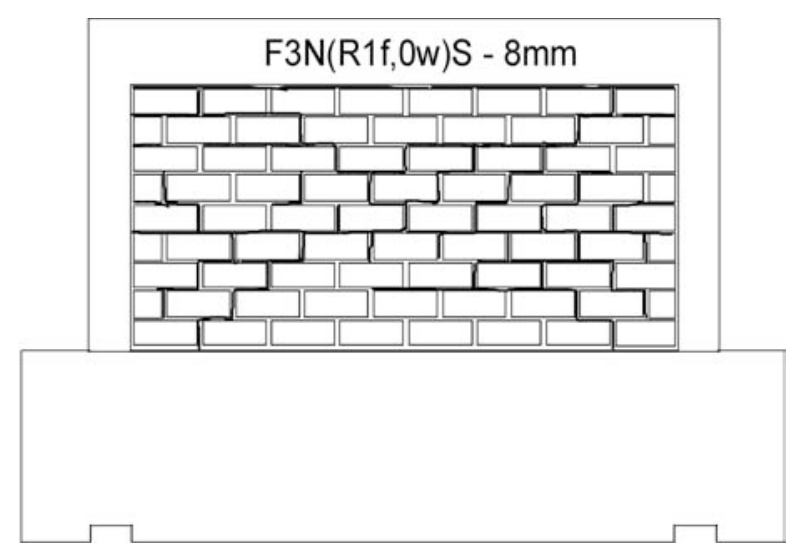

a) Damage pattern [16]

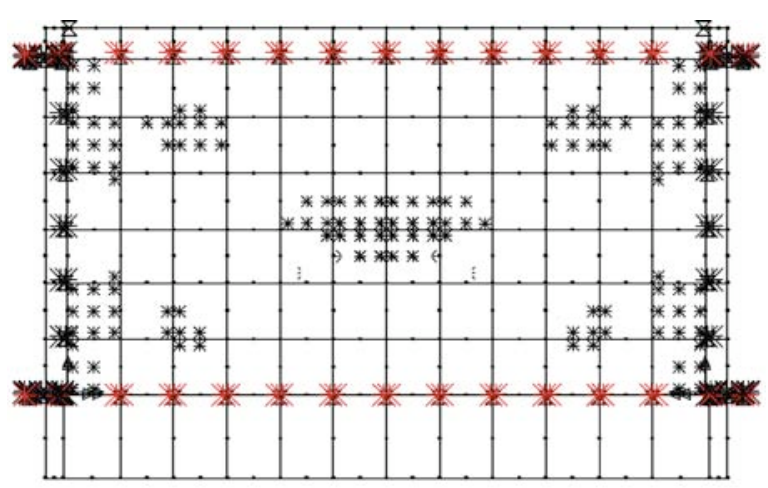

b) Damage pattern [18]

Fig. (20). (a) Damage pattern of masonry infill observed experimentally for infilled frame F3N(R1f,0w)s, b) Damage pattern(x) predicted numerically.

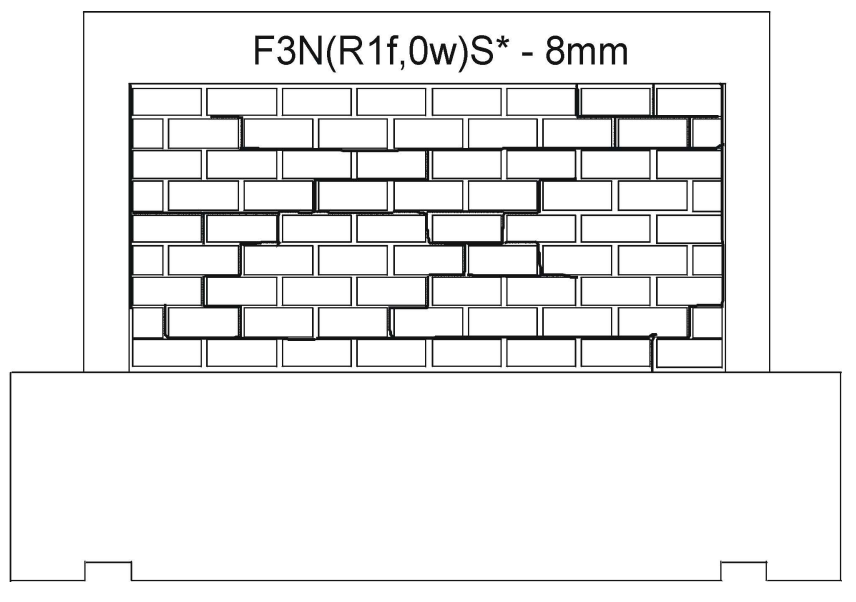

a) Damage pattern [16]

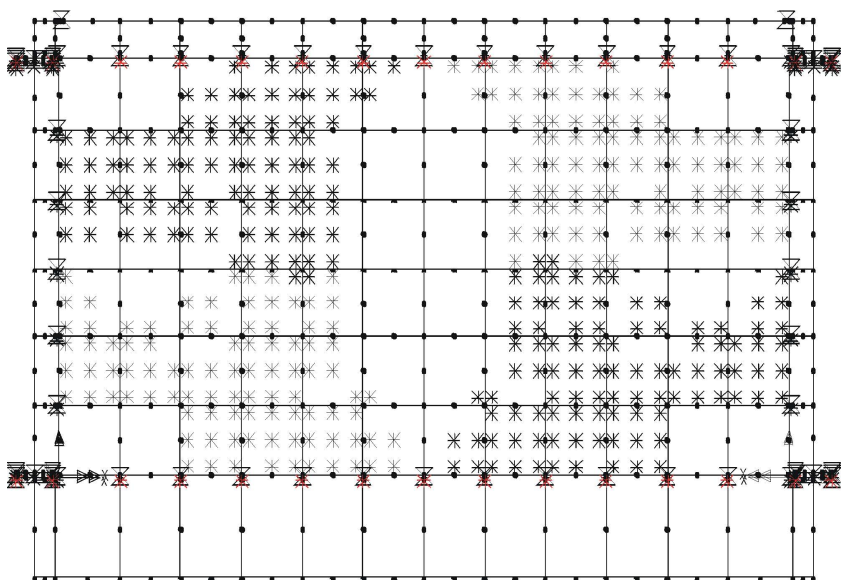

b) Damage pattern [18]

Fig. (21). (a) Damage pattern of masonry infill observed experimentally for infilled frame F3N(R1f,0w)s*, b) Damage pattern(x) predicted numerically.

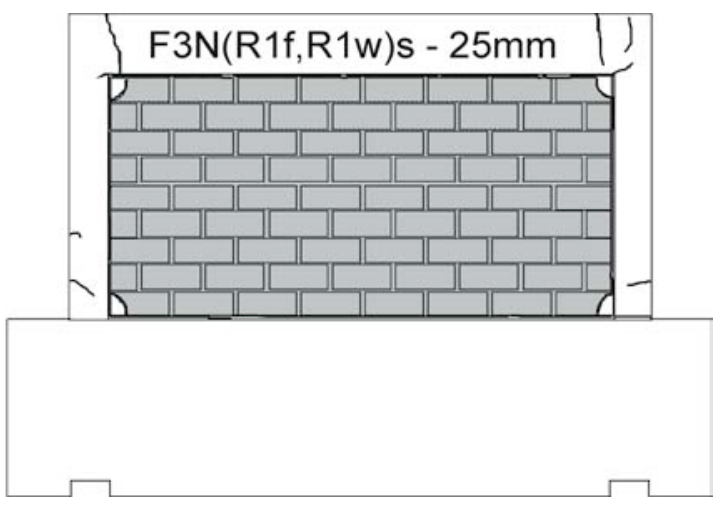

a) Damage pattern [16]

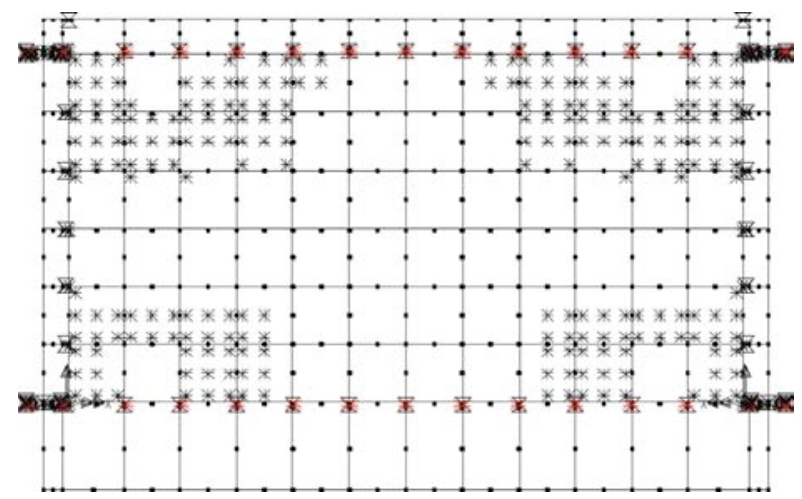

b) Damage pattern [18]

Fig. (22). (a) Damage pattern of masonry infill observed experimentally for infilled frame F3N(R1f,R1w)s, b) Damage pattern(x) predicted numerically.

2. The equivalent diagonal strut will be a multi-linear model, active in compression only. Its force - displacement properties are defined by a "pushover" type of analysis in such a way that the total force - displacement response of the $\mathrm{R} / \mathrm{C}$ infill frame, with the diagonal strut in-place, in terms of envelope curve, is as close as possible to the envelope curve of the numerical simulation of the same problem whereby the contact interface and the masonry infill were simulated separately (sections 2.3 and 2.2 , respectively). 
3. Because the non-linear mechanisms and its properties of the $\mathrm{R} / \mathrm{C}$ frame standing alone remain the same the nonlinear response that arises at either the interface or at the masonry infill, which were addressed separately by the simulation of sections 2.3 and 2.2 , is approximated this time in a combined way, utilizing the multi-linear equivalent diagonal strut approximation. It is obvious that through this simplified numerical treatment one loses the directness of treating this problem with a clear representation of the various non-linear mechanisms as they physically occur at either the contact interface or the masonry infill. Moreover, the degree of approximation of the masonry infill - contact interface - R/C frame interaction by the equivalent diagonal strut is based on the validity of the full non-linear treatment of the masonry infill - contact interface - R/C frame problem, which was demonstrated in sections 2.1. to 2.3.

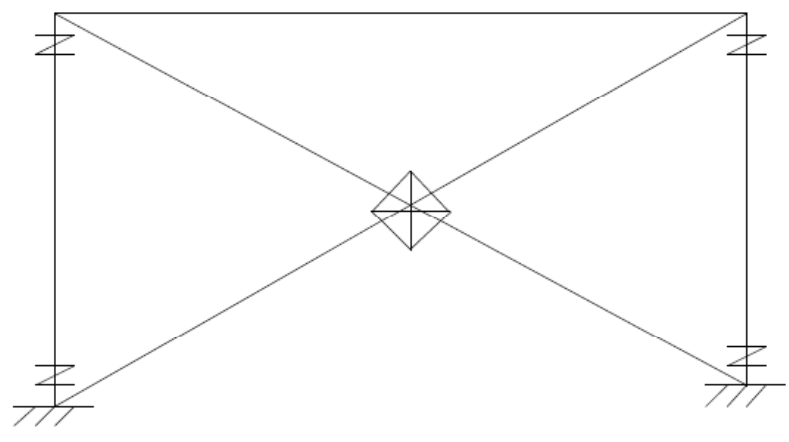

Fig. (23). Equivalent diagonal strut model.

The purpose for this simplification is to numerically simulate by this simplified numerical approximation the response of multi-story infilled $\mathrm{R} / \mathrm{C}$ frames, as will be discussed in the following section 3, based on the successful representation by the multi-linear equivalent diagonal strut model of each of the individual single-bay one-story infilled frame, that such a multi-story frame can be decomposed. In order to verify the degree of approximation of this simplified approach it will be applied in two distinct cases. First, the scaled models presented in section 2.4. namely specimen F1N (Fig. 11) and specimen F3N(R1f,R1w)s (Fig. 16), will be simulated. In this case the results from the simplified approach utilizing a tri-linear diagonal strut model will be compared to the corresponding numerical results of the more explicit numerical simulation (fully non-linear) presented in sections 2.1. to 2.3. as well as with the corresponding experimental results. Figs. (24a) and (24b) depict the comparison of the predicted behavior, in terms of envelope curves resulting from a "pushover" type of loading, whereby the infill was simulated with a tri-linear equivalent strut with the corresponding behavior of the same infill frame that was simulated according to the fully non-linear treatment presented in section 2.3. and 2.4. This is done for specimen F1N in Fig. (24a) and for specimen F3N(R1f,R1w)s in Fig. (24b). The envelope curve as resulted from the experiments is also plotted in this figure. As can be seen, the envelope curve predicted with the tri-linear diagonal strut compares quite well to both the experimental envelope curve as well as to the one resulting from the fully non-linear treatment. This

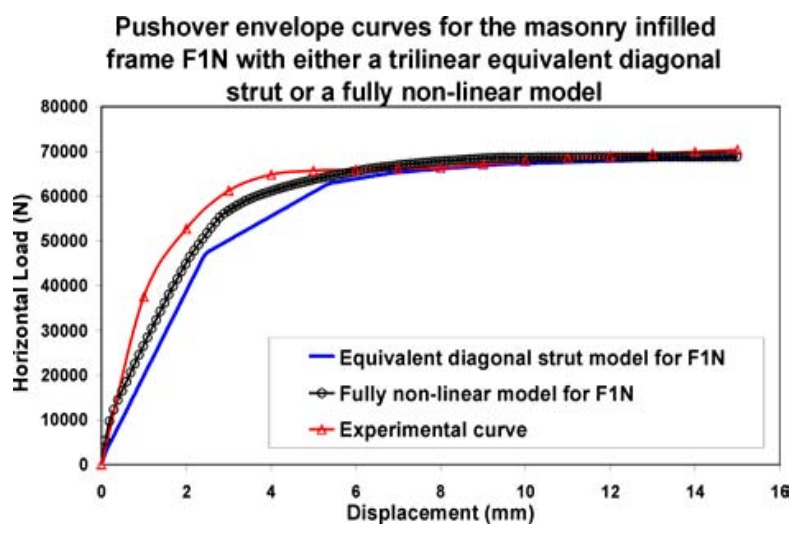

Fig. (24). (a) Comparison of envelope curves for masonry infilled model frame F1N.

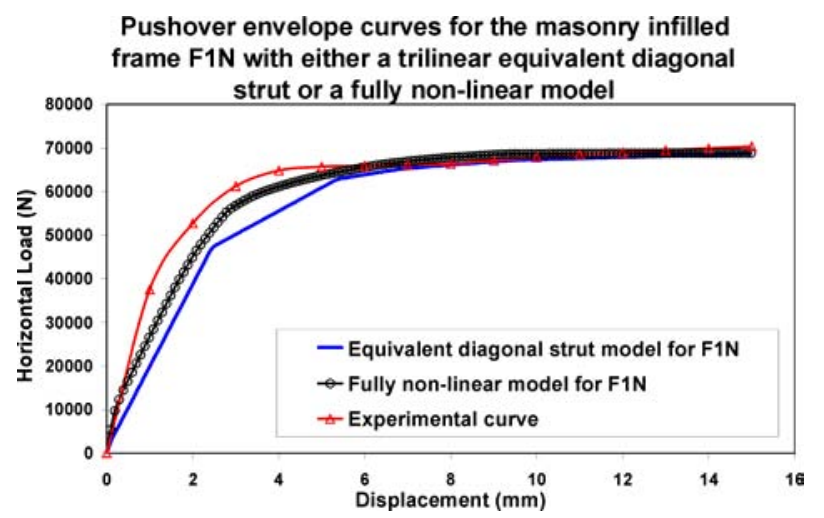

Fig. (24). (b) Comparison of envelope curves for masonry infilled model frame F3N(R1f,R1w)s.

was achieved by a relatively small number of trials for the properties of the diagonal struts retaining the same numerical simulation for the surrounding $\mathrm{R} / \mathrm{C}$ frame for both numerical simulations as the one described in section 2.1. This comparison is extended for the case of cycling loading that was utilized during the experiments, as depicted in Fig. (3). The properties of the tri-linear diagonal strut model defined before were kept unaltered. The numerical results obtained this time by employing either the tri-linear diagonal strut simulation for the masonry infill or the fully non-linear treatment are compared in Figs. (25a) and (25b) for specimens F1N and $\mathrm{F} 3 \mathrm{~N}(\mathrm{R} 1 \mathrm{f}, \mathrm{R} 1 \mathrm{w}) \mathrm{s}$, respectively. In these figures, the experimental load-displacement $(\mathrm{P}-\delta)$ curves, recorded during testing, are also plotted. As can be seen, the (P- $\delta$ ) cycling curves predicted with the tri-linear diagonal strut compare quite well to both the corresponding $(\mathrm{P}-\delta)$ curves obtained from the experiments as well as with the ones resulting from the fully non-linear treatment (sections 2.1. to 2.3).

It must also be underlined again that the degree of approximation of the masonry infill - contact interface - R/C frame interaction by the equivalent diagonal strut is based on the validity of the full non-linear treatment of the masonry infill - contact interface - R/C frame problem, which was demonstrated in sections 2.1. to 2.3. The duration of the fully non-linear cyclic numerical simulation is 30minutes with 424Mbytes memory requirements whereas the simulation of the cyclic response with the equivalent diagonal strut lasts 20 minutes with 221Mbytes memory requirements. The "pushover" analysis for defining the multi-linear properties 


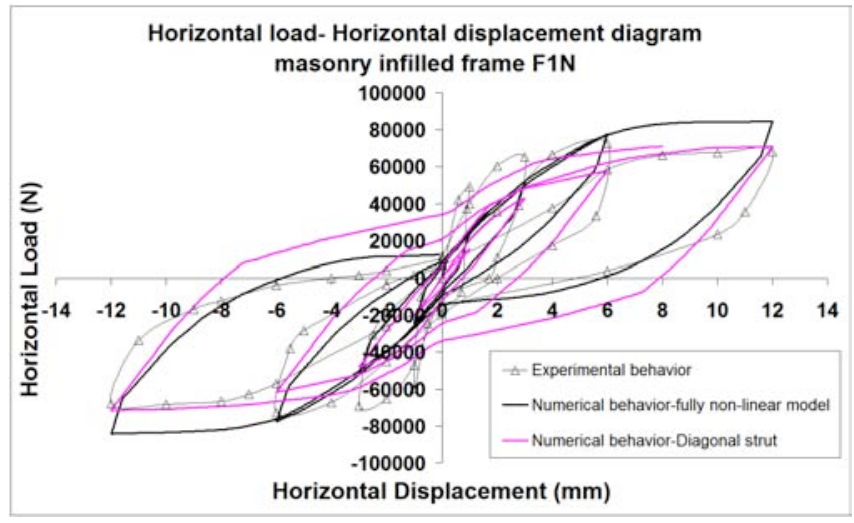

Fig. (25). (a) Comparison of cyclic response for specimen F1N.

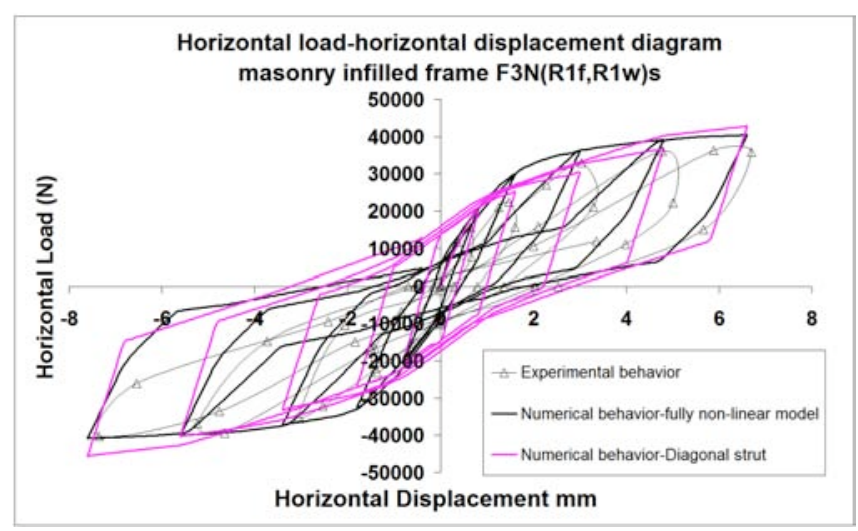

Fig. (25). (b) Comparison of cyclic response for specimen F3N(R1f,R1w)s.

of the equivalent diagonal strut lasts less than 50seconds with relatively low memory requirements. These computer time and computer memory values are from analyses that were performed on a computer with the following specifications: AMD Athlon (tm) $64 \times 2$ dual, core processor $4200+2,20 \mathrm{GHz}, 896 \mathrm{MB}$ Ram. Thus, considerable gains in terms of computer time as well as computer memory requirements results from adopting the multi-linear diagonal strut approximation together with a "pushover" type of analysis. The application of such a simplification for multistory $\mathrm{R} / \mathrm{C}$ infilled frames is outlined in section 3.

\section{AN EQUIVALENT STEP-BY-STEP ELASTIC ANALYSIS FOR MULTI-STORY R/C BUILDINGS WITH MASONRY INFILL}

\subsection{Outline of the Methodology}

Previous studies as well as the extensive experimental and numerical investigation conducted before by the authors and briefly reported here demonstrated that the stiffness and strength added in single-story $\mathrm{R} / \mathrm{C}$ frames through the use of masonry infills can be affected by various non-linear mechanisms such as:

a) The non-linear behaviour of the $\mathrm{R} / \mathrm{C}$ frame.

b) The non-linear mechanisms that develop at the interface between the $\mathrm{R} / \mathrm{C}$ frame and the masonry infill with the individual mechanical properties and their interactions. c) The level of shear deformation that develops in the masonry infill and consequently its non-linear behaviour for that level of shear deformation.

Consequently, the development of all these non-linear mechanisms dictates the total behaviour of masonry infill frames and renders an elastic type of analysis a crude approximation. In the first part of this paper (section 2) it was shown that all these (a to c) non-linear mechanisms are quite successfully simulated numerically by the proposed "fully non-linear" numerical treatment, which will be designated in this section as type A numerical simulation.

The major obstacle in extending this type of full nonlinear numerical treatment (simulation type A) to a multistory masonry-infilled $\mathrm{R} / \mathrm{C}$ frame structure, in order to simulate separately all these non-linear mechanisms for the $\mathrm{R} / \mathrm{C}$ frame members, the masonry infills, and the interfaces between the $\mathrm{R} / \mathrm{C}$ frames and masonry infills, is the computational time and computer memory requirements needed for the completion of such numerical analysis. It is believed that all these dominant non-linear mechanisms that develop in a single-story masonry infilled $\mathrm{R} / \mathrm{C}$ frame, as described in the first part of this paper, can also develop in the same way in a multi-story R/C frame structure with masonry infills when subjected to "seismic type" loading. In the second part of this paper, presented in this section, the non-linear response of masonry infilled multi-story framed R/C planar structural formations is addressed through a step-by-step equivalent post-elastic "pushover" analysis to confront the obstacle of the high computational requirements of the fully non-linear approach; this is done by utilizing the full non-linear response of a number of "single-story" infilled frame units that such a multi-story structure can be decomposed to. It must be stressed that only in-plane stiffness and strength variation of these masonry infilled units is considered in this approximation whereas the out-of-plane behaviour and its possible effects, although important, are not addressed.

Pushover analysis is a nonlinear static procedure which validity and applicability have been extensively studied in literature. According to Eurocode 8 Part 3 (EN 1998-3): paragraph 4.4 .4 (1) Nonlinear static ("pushover") analysis is a non-linear static analysis under constant gravity loads and monotonically increasing horizontal loads. (2) Buildings not complying with the criteria for regularity in plan shall be analysed using a spatial model. (3) For buildings complying with the regularity criteria the analysis may be performed using two planar models, one for each main direction.

According to Eurocode 8 Part 1 (EN 1998-1):4.3.3.4.2.3 (1) The relation between base shear force and the control displacement (the "capacity curve") should be determined by "pushover" analysis for values of the control displacement ranging between zero and the value corresponding to $150 \%$ of the target displacement. (2) The control displacement may be taken at the centre of mass of the roof of the building. The top of a penthouse should not be considered as the roof.

This approximate "pushover" analysis, outlined in the following steps a1 to h1 and summarized in Table 6, deals with the non-linear behaviour of masonry infilled multi-story $\mathrm{R} / \mathrm{C}$ frames, with respect to their in-plane stiffness and strength variation, utilising the findings of the in-depth re- 
search in the behaviour of the single-story masonry infill $\mathrm{R} / \mathrm{C}$ frame units; this was presented in the first part of this paper (section 2) and is also included in the work reported by Manos, Soulis and Thaumpteh ([11, 16-18]). The objective of this section is to approximate the complex behaviour of multi-story R/C infilled frames by applying the simplified equivalent diagonal strut simulation briefly presented in section 2.5 , so that a realistic solution of such practical problems becomes attainable in terms of computer time and computer memory requirements.

An equivalent post-elastic numerical simulation is proposed (Type B simulation) for multi-story R/C frame structural formations that include masonry infills. This type B simulation is built assuming that the masonry infills are simulated with diagonal strut members, having multi-linear mechanical characteristics, whereas the R/C structural members have the capability of developing plastic hinges at their ends, as described in section 2.1. Steps a1 to h1 are then followed.

a1) This multi-story structural formation is decomposed to a number of individual single-story masonry infilled frame units that are grouped according to their common geometric and mechanical characteristics of the R/C elements and their masonry infills, in order to minimize in this way the number of different units to be analysed in the next steps (steps b1 to e1).

b1)For each one of these single-story masonry infilled R/C frame units a simulation type A is prepared in order to obtain through a "pushover" type of analysis the full nonlinear response for each individual single-story masonry infilled $\mathrm{R} / \mathrm{C}$ frame composing the multi-story structural formation. As described in sections 2.1., 2.2., and 2.3. of this paper this type A simulation includes the following:

The numerical simulation of the masonry infill utilizing non-linear plane stress finite elements (section 2.2.).

The numerical simulation of the surrounding $\mathrm{R} / \mathrm{C}$ frame with linear elastic beam and column members together with predetermined locations of possible plastic hinge formation at the ends of each element (section 2.1.).

The numerical simulation of the interface between the $\mathrm{R} / \mathrm{C}$ frame and the masonry infill with 2-D non-linear joint elements in the axial and transverse direction (section 2.3.).

c1) For each one of these single-story masonry infilled R/C frame units a "pushover" type A analysis is performed and the horizontal load $(\mathrm{H})$ versus horizontal displacement $(\delta)$ or shear strain $(\gamma)$ response curve is obtained, as indicated by (Fig. 26). The accumulation of damage to the masonry infills is also obtained linked to the increase of the shear strain levels as it results from this fully non-linear type A simulation (as indicated in Figs. (27a) to (27f).

d1)For each one of these single-story masonry infilled R/C frame units a number of type B simulations are next prepared. Each one of these type B simulations assumes that the R/C members of the surrounding frame retain their capability of developing plastic hinges at their ends as in b1) above whereas the masonry infill is replaced with an equivalent multi-linear diagonal strut member with properties as explained in e1) below.

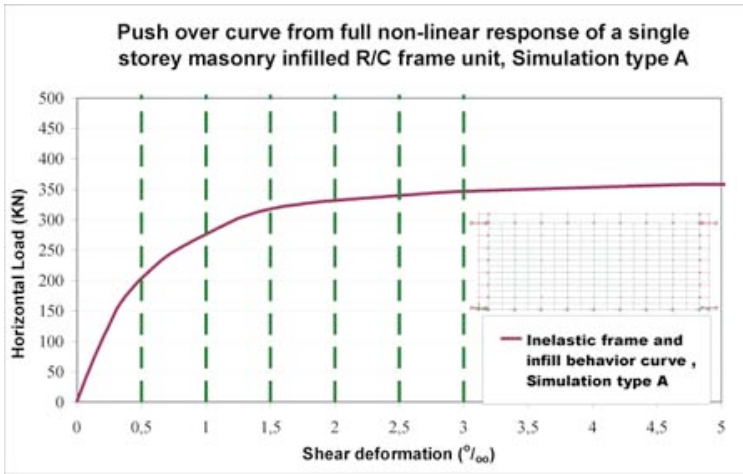

Fig. (26). The fully non-linear type A response, obtained for each single-story frame.

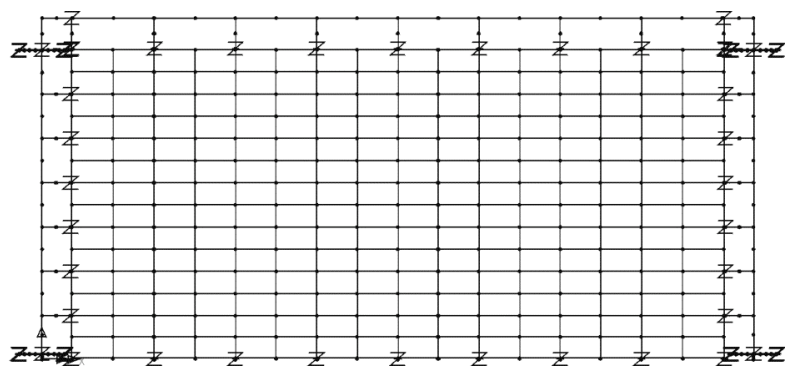

Fig. (27). (a) State of masonry damage at strain level $0.0 \%$.

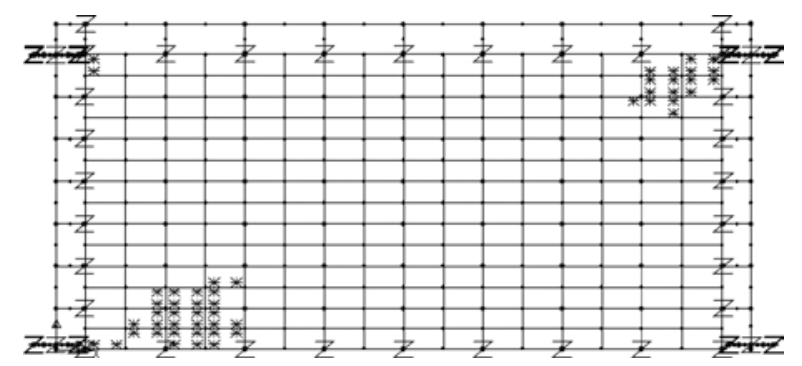

Fig. (27) (b) State of masonry damage at strain level 1.0\%.

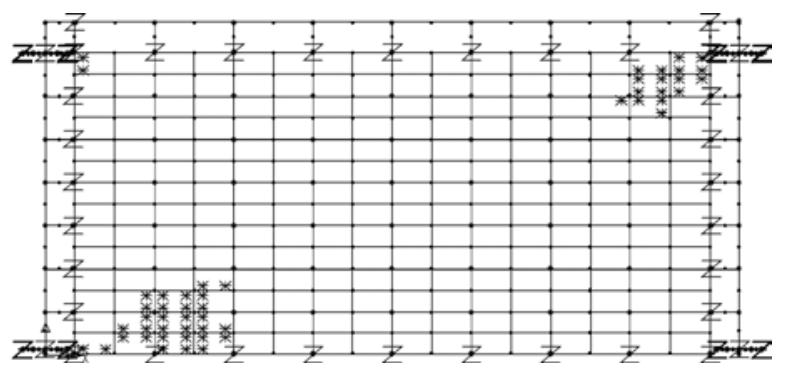

Fig. (27). (c) State of masonry damage at strain level 1.5\%.

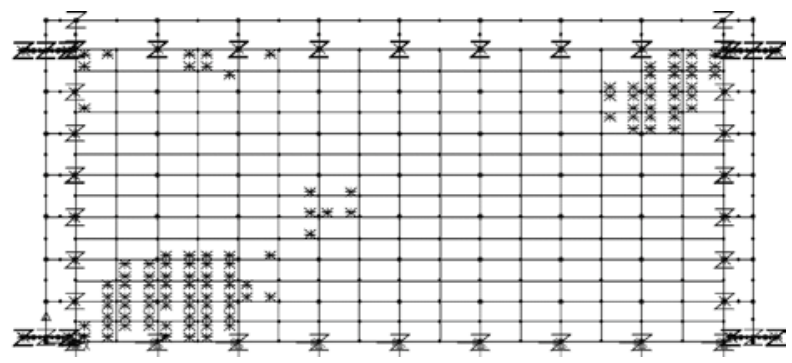

Fig. (27). (d) State of masonry damage at strain level $2.0 \%$. 
Fig. (27). Contd....

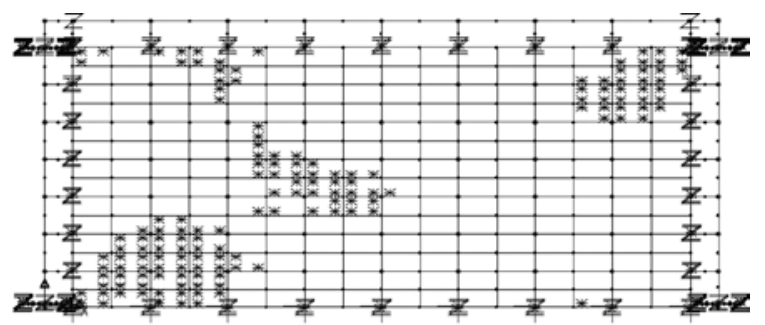

Fig. (27). (e) State of masonry damage at strain level $2.5 \%$.

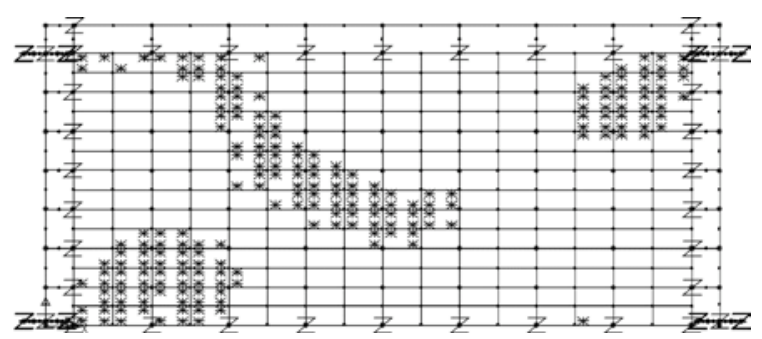

Fig. (27). (f) State of masonry damage at strain level $3.0 \%$.

e1) A "pushover" type B analysis is now performed for the same single-story units of step $\mathrm{d} 1$; the objective here is to obtain horizontal load $(\mathrm{H})$ versus horizontal displacement $(\delta)$ or shear strain $(\gamma)$ response for a number of inter-story drift values corresponding to a number of pre-selected shear-strain levels for the masonry infill (e.g. $0.1 \%$, $0.15 \%, 0.2 \%, 0.25 \%, 0.3 \%$, etc.). The type $\mathrm{B}$ response results should be in reasonable agreement with the response values obtained through the fully non-linear type A simulation for the same infill masonry single-story frame unit. This is achieved through a trial and error approach by adjusting properly in the type $\mathrm{B}$ analysis the multi-linear properties of the diagonal strut that replaces the masonry infill for each one of the single-story masonry infill $\mathrm{R} / \mathrm{C}$ frame units studied by type A simulation in step c1. This is shown in Fig. (28) for one such masonry infilled frame unit.

f1) In order to predict the performance of the multistory structural formation through such a type B simulation a "pushover" analysis is performed next whereby all the $\mathrm{R} / \mathrm{C}$ members of the multi-story structure retain their capability of developing plastic hinges at their ends as in b1) and e1) above whereas all the masonry infills are replaced with an equivalent multi-linear diagonal strut member with properties found in the previous step (e1).

g1) At pre-selected intervals (i+1) of this "pushover" analysis of the multi-story structure with target top story displacement corresponding to shear strain levels already examined in steps d1) and e1) (e.g. $0.1 \%, 0.15 \%, 0.2 \%$, $0.25 \%, 0.3 \%$, etc. ) the actual story displacements and forces as well as the shear-strain levels $\gamma_{i+1}$. for each masonry infill are recorded.

h1)The performance of each masonry infill for the multistory structure is assessed through the corresponding individual masonry infilled $\mathrm{R} / \mathrm{C}$ frame unit forming the multi-story structural formation, as found in step $\mathrm{c} 1$. This is done by using the corresponding full non-linear re- sponse type A simulation (see description of step c1) and the obtained in interval $i+1$ of step g1) values of the shear strains $\boldsymbol{\gamma}_{\mathbf{i}+\mathbf{1}}$, for each masonry infill of the multi-story structure. In this way, the expected performance (development and propagation of damage) can be deduced for each masonry infill of the multi-story structure, as shown in the Figs. (29a) and (29b).

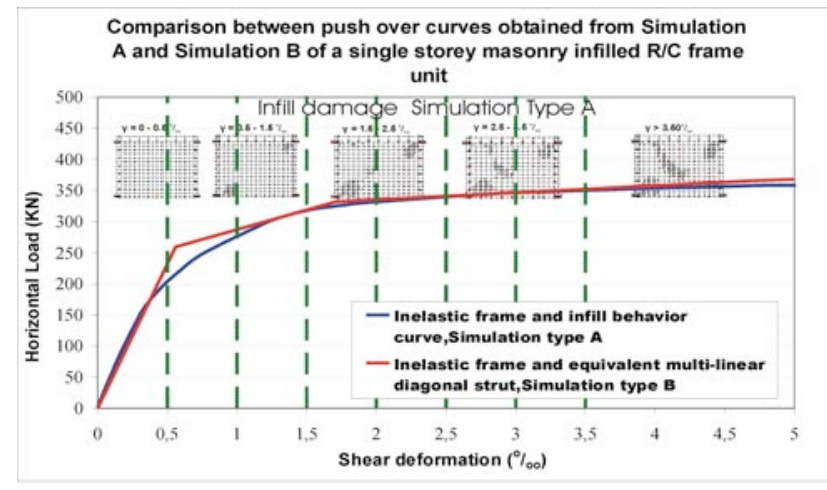

Fig. (28). The properties of a Multi-linear diagonal strut are found approximating for each single-story infilled frame the stiffness and strength variation as obtained from its fully non-linear A type simulation. This is done for preselected shear strain values (e.g. $0.1 \%$, $015 \%, 0.2 \%, 0.25 \%, 0.30 \%$ and $0.35 \%$ ).

\subsection{Validation of the Proposed Equivalent Step-by-Step Type B Analysis}

A six-story masonry infilled planar frame structural formation is selected for the validation of the proposed method of analysis when this structure is subjected to seismic-type horizontal loading. More specifically an outer planar section of a 6-story masonry infilled $\mathrm{R} / \mathrm{C}$ building is studied. The results from the application of the proposed step-by-step equivalent "pushover" type B analysis for this 6-story R/C frame with masonry infills will be compared with the results from a "pushover" fully non-linear type A numerical simulation of the same structure.

\subsubsection{Description of the 6- Story $R / C$ Building Numerical Simulation}

A characteristic plan view of the 6-story masonry infilled $\mathrm{R} / \mathrm{C}$ building is shown in Fig. (30).The outer facade of this 6 -story building is shown in the Figs. (30) and (31). Only a section in the large dimension of the structure will be utilized for the application of the proposed analysis (Fig. 31).

The height of the structure is $18 \mathrm{~m}$. Table 7 lists the cross sections of the columns and beams together with a cross section of wall of the 6-story structure. The following vertical loads are imposed apart from the self-weight:

The self-weight of the masonry infills $\left(3,6 \mathrm{KN} / \mathrm{m}^{2}\right)$, applied at the perimeter of the structure.

The validation of the proposed equivalent type B "pushover" analysis for frame No. 4 will proceed as described in Table 6 and outlined in section 3.1. Fig. (32a) depicts the 


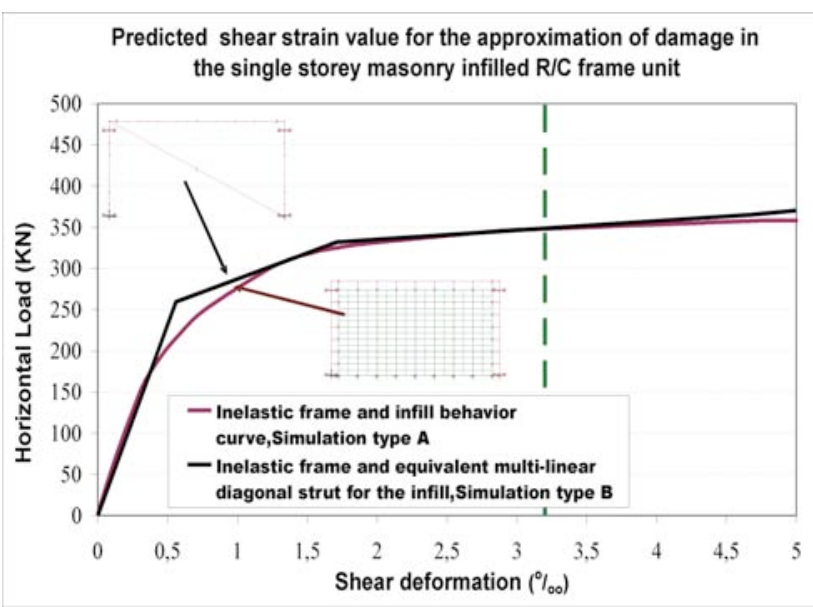

Fig. (29). (a) For strain $\gamma_{\mathrm{i}+\mathbf{1}}$ (e.g. $3,2 \%$ ) of the type B simulation find from step c1) of type A simulation the masonry infill damage.

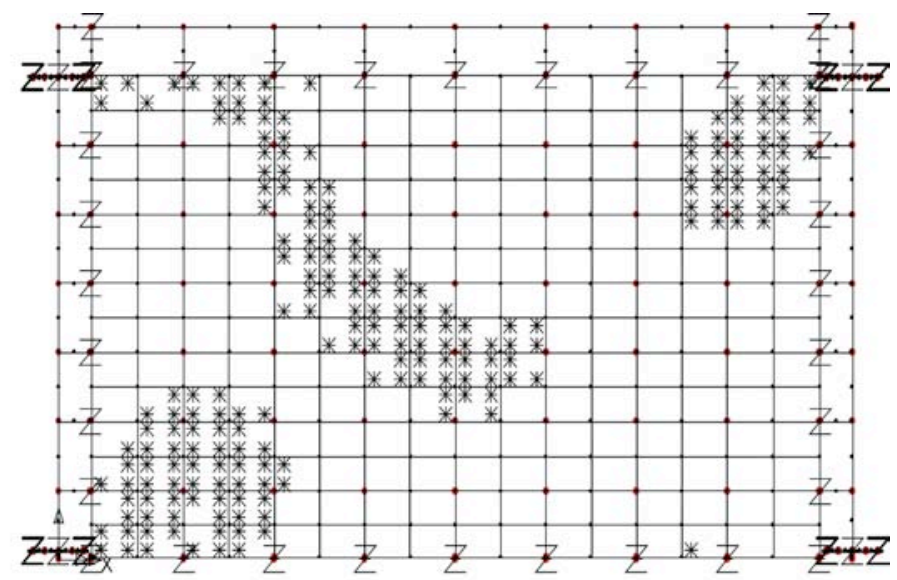

Fig. (29). (b) Damage pattern of the infill, as predicted from the full non-linear analysis (type A) for the shear strain level $3,2 \%$.

Table 6. Steps of Equivalent Step by Step Elastic Analysis for the Examination of the Ultimate State of Masonry Infills

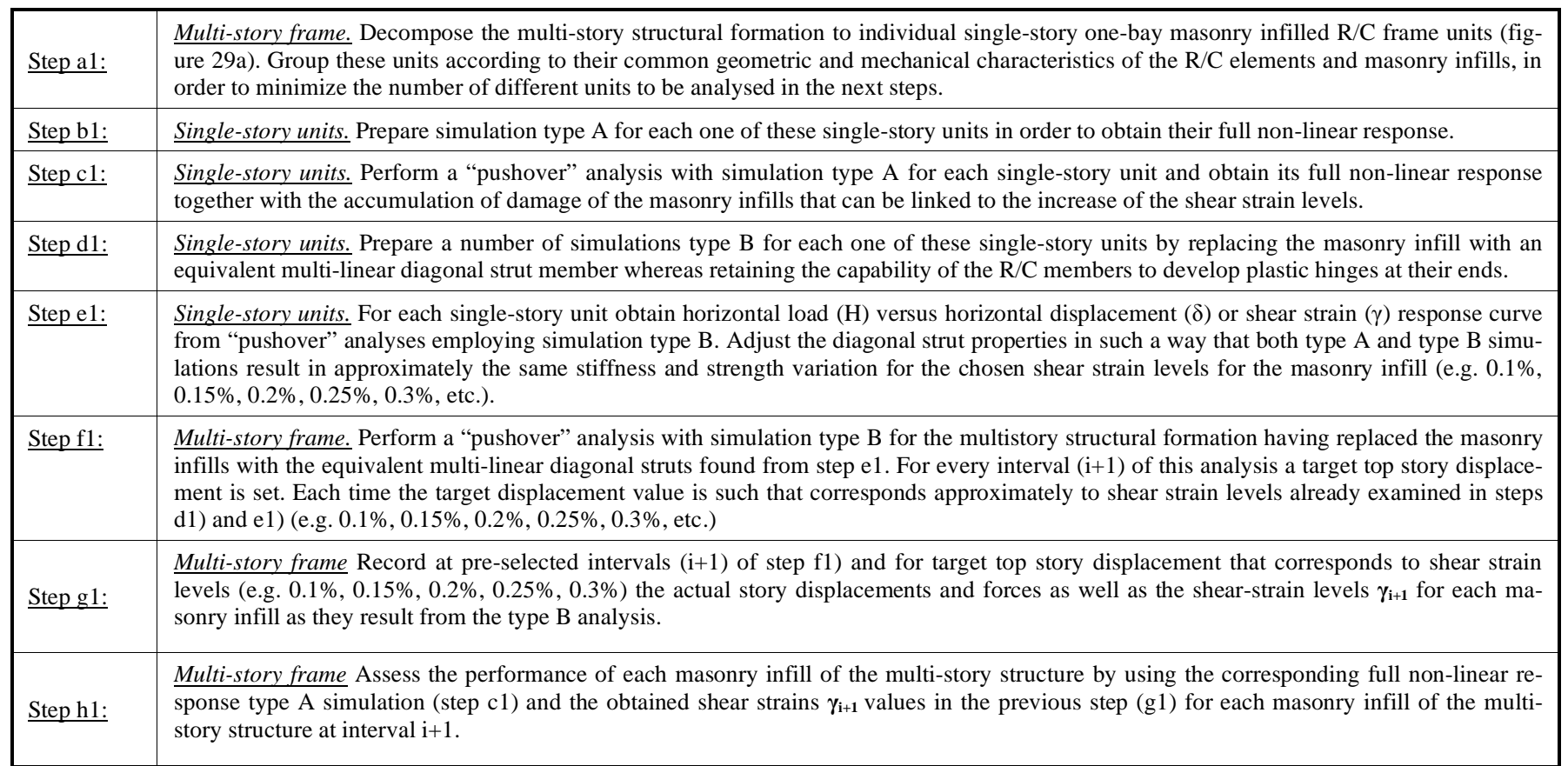




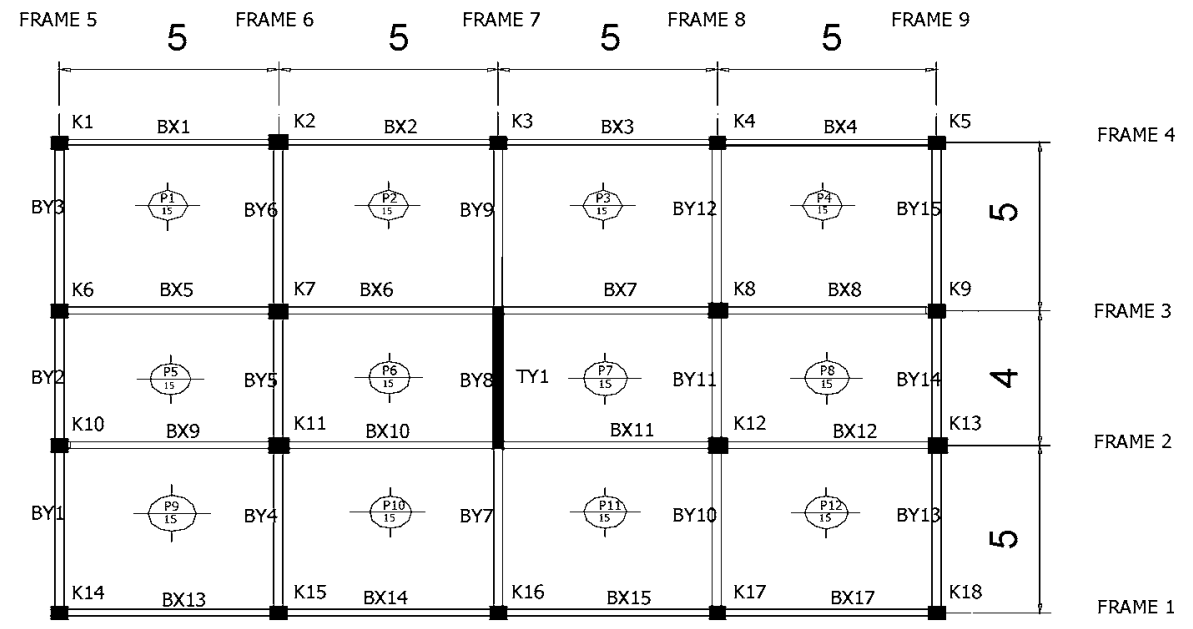

Fig. (30). Plan of a typical floor level (dimensions in meters).
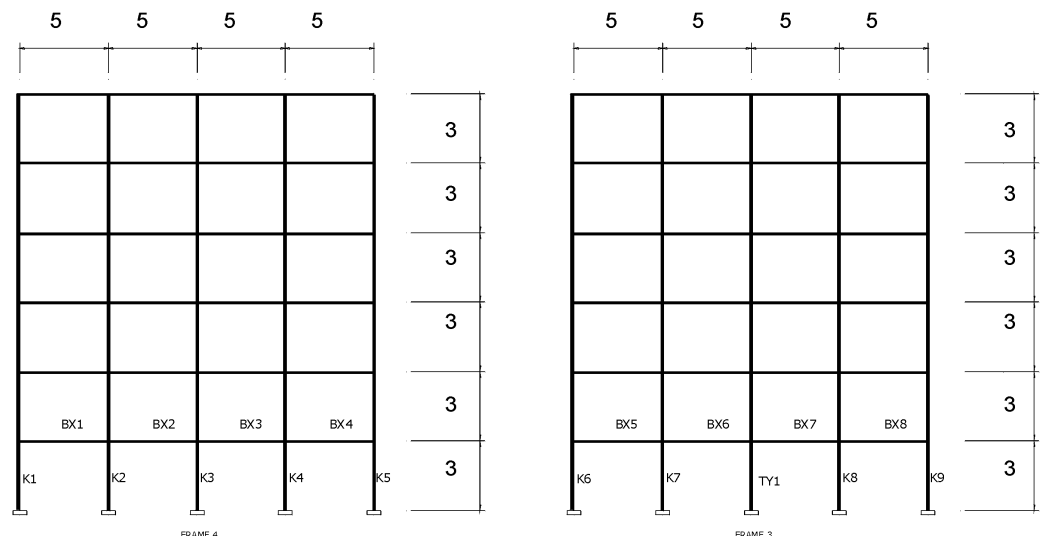

Fig. (31). Typical section of structure, frames 1-4, (dimensions in meters).

Table 7. Cross Sections of Columns, Beams and Wall of the 6-Story Structure

\begin{tabular}{|l|l|l|l|l|l|l|}
\hline Story & $\begin{array}{l}\text { Columns K1-K5, K14-K18 } \\
\mathrm{K} 6, \mathrm{~K} 9, \mathrm{~K} 10, \mathrm{~K} 13\end{array}$ & $\begin{array}{l}\text { Columns } \\
\mathrm{K} 7-\mathrm{K} 8-\mathrm{K} 11-\mathrm{K} 12\end{array}$ & $\begin{array}{l}\text { Shear Wall } \\
\mathrm{TYi}\end{array}$ & $\begin{array}{l}\text { Beam } \\
\mathrm{BXi}_{(1,17)}\end{array}$ & $\begin{array}{l}\text { Beam } \\
\mathrm{BYi}_{(1,7,9,15)}\end{array}$ \\
\hline \hline $1^{\text {os }}-5^{\text {os }}$ & $40 / 40$ & $45 / 45$ & $400 / 25$ & $20 / 60$ & $20 / 60$ \\
\hline
\end{tabular}

The marble coating of each floor $1,3 \mathrm{kN} / \mathrm{m}^{2}$

Imposed vertical live load is assumed to be $\mathrm{Q}=2 \mathrm{kN} / \mathrm{m}^{2}$

numerical simulation of frame No. 4 whereby the masonry infills are simulated as multi-linear diagonal strut members (Simulation type B) whereas Fig. (32b) depicts the fully nonlinear simulation of the $\mathrm{R} / \mathrm{C}$ frame with the masonry infills and their contact interfaces (simulation type A, section 2). For the fully non-linear "pushover" type A analysis of the 6story structure, the maximum target displacement at the top was set equal to $35 \mathrm{~mm}$, with the displacement profile along the height of the building assumed to be triangular. The resulting in this way displacements were imposed at each floor level in a gradual increasing fashion. The corresponding lat- eral forces at each floor level resulting from this fully nonlinear analysis were recorded especially for horizontal maximum top displacement levels of $10 \mathrm{~mm}, 20 \mathrm{~mm}, 25 \mathrm{~mm}$ and $35 \mathrm{~mm}$. The corresponding deformation pattern of the whole structure at each floor level was predicted by both type A and type B simulations. By comparing the loaddeformation obtained through either the type A (fully nonlinear approach) or the type B (equivalent post-elastic with multi-linear struts approach) the validity of the type B approximation of the masonry infill response will be assessed.

The following are also assumed to be valid: 
- The properties of beam elements are based on the Tbeam elements cross-sections.

- Very close to column to beam connection the region is regarded as rigid.

- Thick beam elements are utilized in the numerical simulation of the column and beam R/C members.

- It is assumed that the frame members are constructed by reinforced concrete (Young Modulus $E=2,9 \times 10^{7} \mathrm{kN} / \mathrm{m}^{2}$, Poisson ratio $v=0,2$, specific weight $\gamma=25 \mathrm{kN} / \mathrm{m}^{3}$ ).

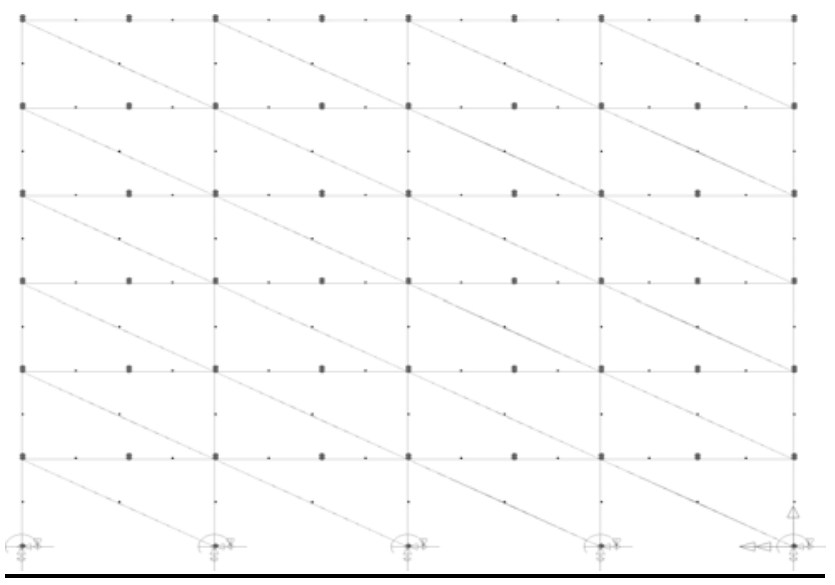

Fig. (32). (a) Type B numerical simulation of 6-story plane structure with masonry infills simulated as diagonal struts.

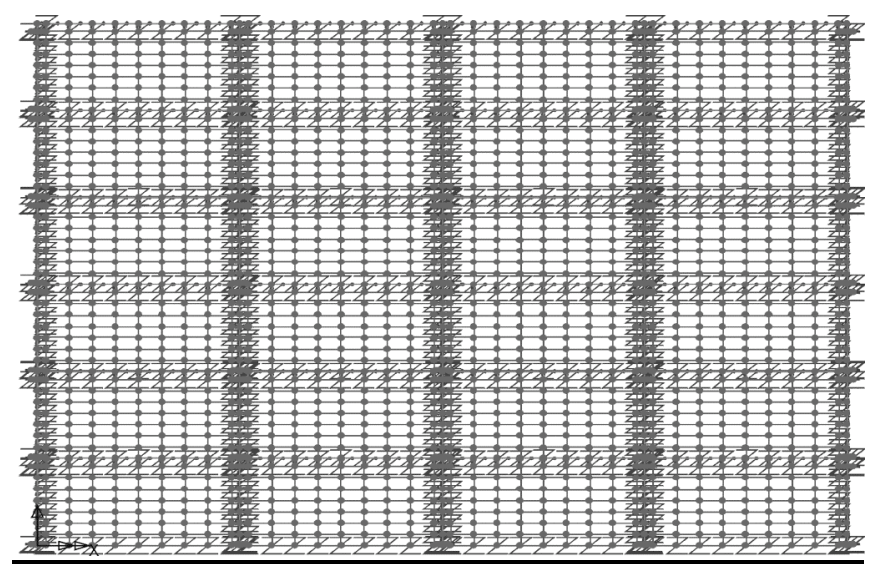

Fig. (32). (b) Type A numerical simulation of 6-story plane structure with masonry infills simulated as plane stress elements.

\subsubsection{Numerical Simulation of the 2-D 6-Story Structure with Masonry Infills}

A) Fully non-linear masonry infilled R/C frame response (simulation type A): The successful numerical simulation that has been proposed in section 2 will be applied first for the whole 6-story structure. The horizontal load-horizontal displacement fully non-linear response curve resulting from this simulation will include non-linear mechanisms for the masonry infill, the surrounding $\mathrm{R} / \mathrm{C}$ frame, the interface between the masonry infill and the surrounding prototype frame. Described briefly in what follows is the numerical simulation of the masonry infill, that of the R/C frame and of the interface between the $\mathrm{R} / \mathrm{C}$ frame and the masonry infill (Figs. (34a, 34b) and (34c).

a) Simulation of the masonry infill. The simulation of the masonry infill, utilizing non-linear plane stress finite elements, was described extensively in section 2 . This is also followed here (Fig. 34b). The isotropic nonlinear material law of Modified Von Mises was utilized. The failure surface of masonry infill is depicted in Fig. (33) together with the adopted mechanical properties of the masonry infill listed in Table 8.

b) Simulation of the beam/column $R / C$ elements and the plastic hinge formation. The simulation of the surrounding $\mathrm{R} / \mathrm{C}$ frame is done with linear elastic beam and column members together with predetermined locations of possible plastic hinge formation at the ends of each element the same way as described in section 2.1 .

c) Simulation of interface between the $R / C$ frame and the masonry infill The numerical simulation of the interface between the prototype $\mathrm{R} / \mathrm{C}$ frame and the masonry infill is done

Table 8. Mechanical Properties and Failure Surface Employed in the Numerical Simulation

\begin{tabular}{|c|c|}
\hline \multicolumn{2}{|c|}{$\begin{array}{l}\text { Mechanical properties used for the simulation of masonry infills for } \\
\text { the 6-story structure }\end{array}$} \\
\hline Young Modulus (N/mm²) & 2500 \\
\hline Poisson Ratio & 0,18 \\
\hline Tensile strength $\left(\mathrm{N} / \mathrm{mm}^{2}\right)$ & 0,2 \\
\hline Compressive strength $\left(\mathrm{N} / \mathrm{mm}^{2}\right)$ & 2,5 \\
\hline Softening Modulus under compression $\left(\mathrm{N} / \mathrm{mm}^{2}\right)$ & 0 \\
\hline Softening Modulus under tension(N/mm²) & 0 \\
\hline
\end{tabular}

Failure surface of the masonry infill of the 6-story stucture (principal stresses $\sigma 1, \sigma 2$ )

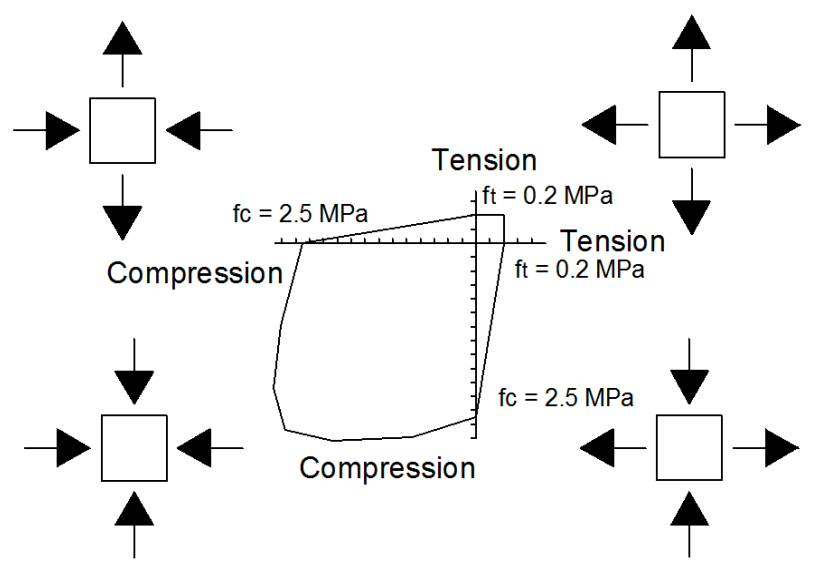

Fig. (33). Failure surface of the masonry infill of the 6-story stucture (plane stress elements). 
Typical single bay frome extracted firom the 6-storey frame structure BX1

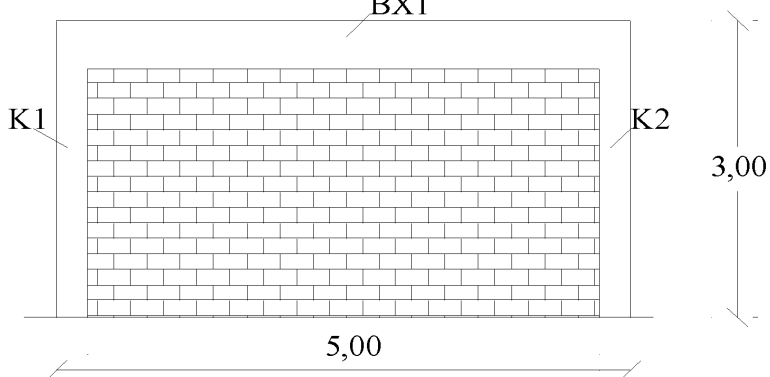

Fig. (34). (a) Typical masonry infilled frame unit of the 6-story building.

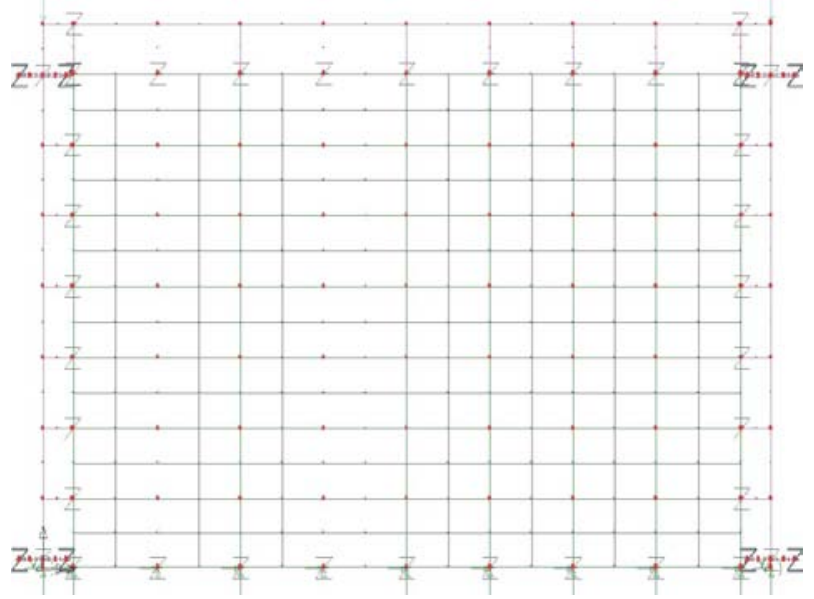

Fig. (34). (b) Fully non-linear masonry infilled R/C frame simulation (type A) : Fig. 34c) Non-linear surrounding R/C frame- with multi-linear diagonal for masonry infill (type B).

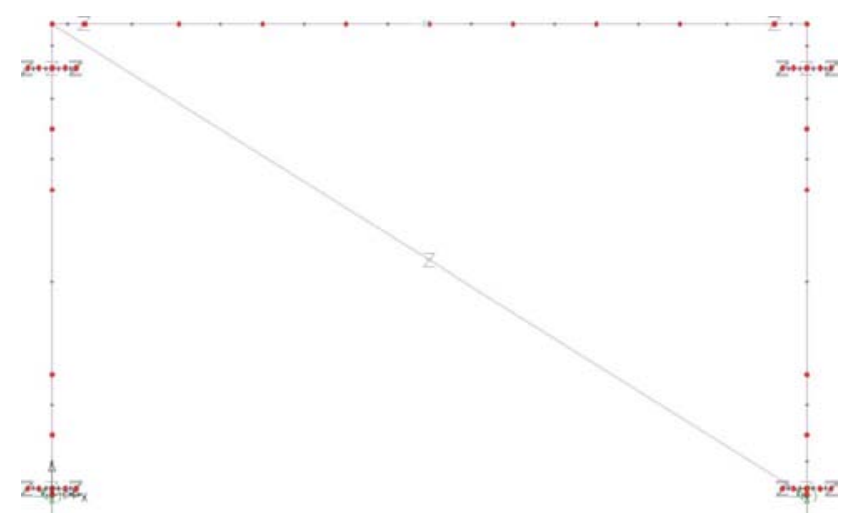

Fig. (34). (c) Non-linear surrounding R/C frame- with multi-linear diagonal for masonry infill (type B).

in the same way as described in section 2.3, utilizing nonlinear joint elements in the axial and transverse direction. This interface is assumed to have been built with mortar type V1 (see Thauampteh [16] and Table 5) with mechanical properties typical to the ones used in the Greek building practice.

B) Non-linear surrounding $\mathrm{R} / \mathrm{C}$ frame with multi-linear diagonal struts (Simulation type B): Next, the proposed equivalent type B numerical simulation that has been proposed in section 3.1. will also be applied for the whole 6story structure.As was done in simulation type A here too the numerical simulation of $\mathrm{R} / \mathrm{C}$ members will be done with linear elastic beam and column elements together with predetermined locations of possible plastic hinge formation at the ends of each element (Fig. 34c). The properties of each equivalent diagonal strut is determined with successive approximations as described in step e1 of section 3.1 and Table 6.

Influences arising from the vertical load. The axial load acting vertically on the columns of the 6-story structure is an important parameter and as such it should be taken into account in both $\mathrm{A}$ and $\mathrm{B}$ types of numerical simulation of the single-story masonry infilled $\mathrm{R} / \mathrm{C}$ frame (steps b1 to e1), acting at the top of the columns of these single-story masonry units. For this purpose, the axial load level acting on the columns of the 6-story structures was determined from the vertical load combination $\mathrm{G}+0,3 \mathrm{Q}$ and is shown in Fig. (35). The mean axial load that is applied at the top of the columns of the $\mathrm{R} / \mathrm{C}$ single-story frames located at the ground floor of the 6-story structure is $438 \mathrm{KN}$. Naturally, the columns of higher storys are subjected to lower axial load values. This will be utilized in the next section.

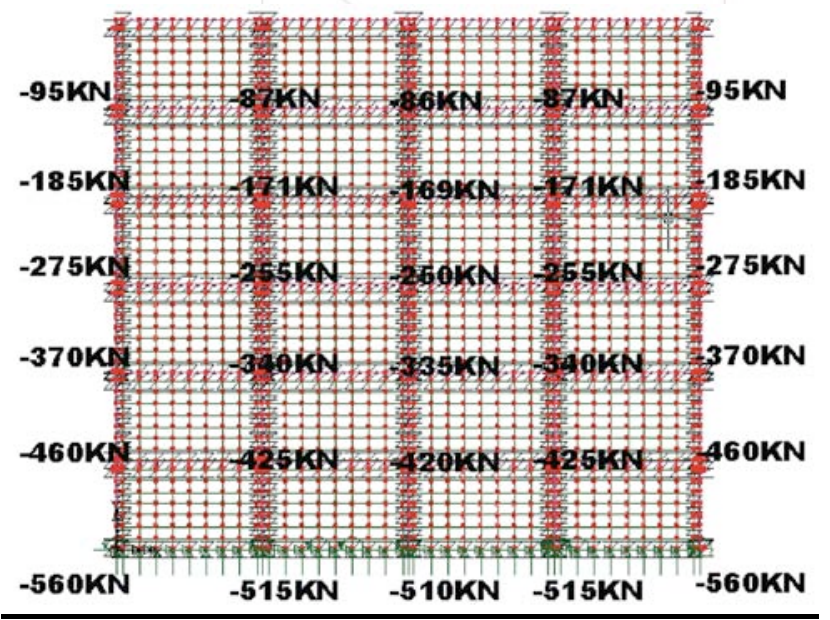

Fig. (35). Axial loads acting on the columns of the 2-d masonry infilled 6-story building.

\subsubsection{Comparison of Results of the Proposed Type B Analysis with those of the fully Non-linear Type A Analysis}

Fig. (36) depicts the base shear - top displacement pattern obtained either by the fully non-linear "pushover" type A analysis for the 6-story structure, when the top displacement reached the target value of $10 \mathrm{~mm}$, or the proposed equivalent type $\mathrm{B}$ analysis with the multi-linear diagonal struts. The target displacement corresponds to approximately $0.1 \%$ shear strain level for the masonry infills. The employed type B simulation is also depicted in the top left of Fig. (36) together with the horizontal story displacements at this maximum shear strain level $(0.1 \%)$. As can be seen, the loaddisplacement response obtained by the step-by-step equivalent post-elastic analysis is in good agreement with that predicted by the fully non-linear analysis. Using the procedure of step h1 of section 3.1., the predicted masonry damage along the height of this structure was also obtained; this is shown at the top right of Fig. (36) as well as in Fig. (37). 


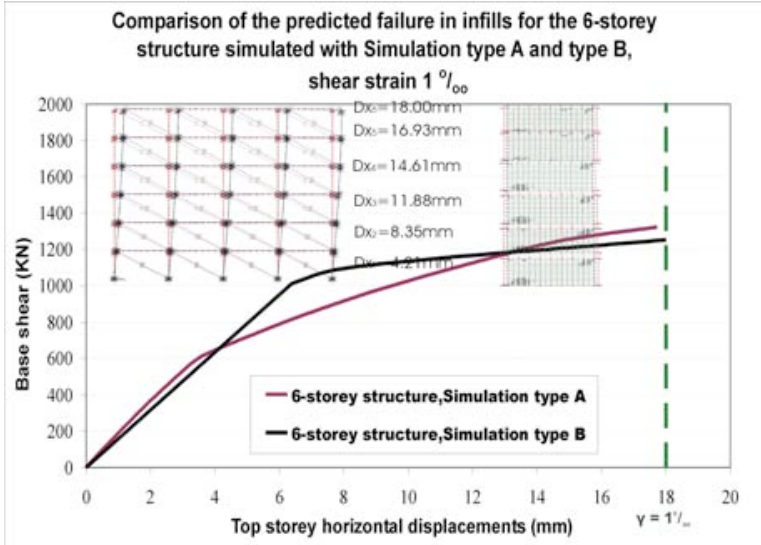

Fig. (36). Base shear - top story displacement "pushover" response as predicted by either type A or type B $(\gamma=0.1 \%)$.

Figs. (37a) and (37b) depict in more detail the predicted damage of the masonry infills of the 6-story structural formation as it resulted from either the fully non-linear type A or the equivalent type B numerical simulations, respectively. As can be seen, good agreement is obtained between the masonry infill damage predictions of the equivalent type analysis with those resulting from the fully non-linear type A approach for the whole 6-story structure.

The same as before is also done for a top story displacement corresponding to either $0.2 \%$ or $0.3 \%$ of the building height. For top story displacement corresponding to $0.2 \%$ of the building height the type $\mathrm{A}$ and $\mathrm{B}$ response curves are depicted in Fig. (38) whereas the relevant damage patterns for either type A or type B analysis are shown in Figs. (39a) and $(39 b)$, respectively. Similarly, for top story displacement corresponding to $0.3 \%$ of the building height the type A and $\mathrm{B}$ response curves are depicted in Fig. (40) whereas the relevant damage patterns for either type or type B analysis are shown in Figs. (41a) and (41b), respectively. As can be seen from these figures there is reasonably good agreement in the pushover "top story versus base shear" response of the 6story structural formation predicted by the equivalent type $B$ analysis with that predicted with the considered more accurate fully non-linear type A analysis. Moreover, there is also reasonably good agreement between the damage patterns of the masonry infills predicted by the type B simulation as explained in step h1) of the outlined methodology in section 3.1 with the corresponding damage patterns of the masonry infills, as predicted by the more accurate fully non-linear type A analysis.

The duration of the fully non-linear cyclic numerical simulation for a maximum shear strain level $\gamma=0.3 \%$ was 95minutes whereas the simulation of the cyclic response with the equivalent diagonal strut lasted 80minutes. The corresponding "pushover" analysis for this strain level when employing the fully non-linear simulation of the masonry infilled frames lasted 50 minutes whereas the "pushover" analysis with diagonal struts lasted 2 minutes and $30 \mathrm{sec}$ onds. Thus, considerable gains in terms of computer time as well as computer memory requirements results from adopting the multi-linear diagonal strut approximation together with a "pushover" type of analysis. One should also add to the time and effort required for the "pushover" analysis with diagonal struts the time and effort needed to define the properties of the diagonal struts for each individual one-bay single story infilled frame that the complex frame structure is decomposed to (step a1 to e1, Table 6).

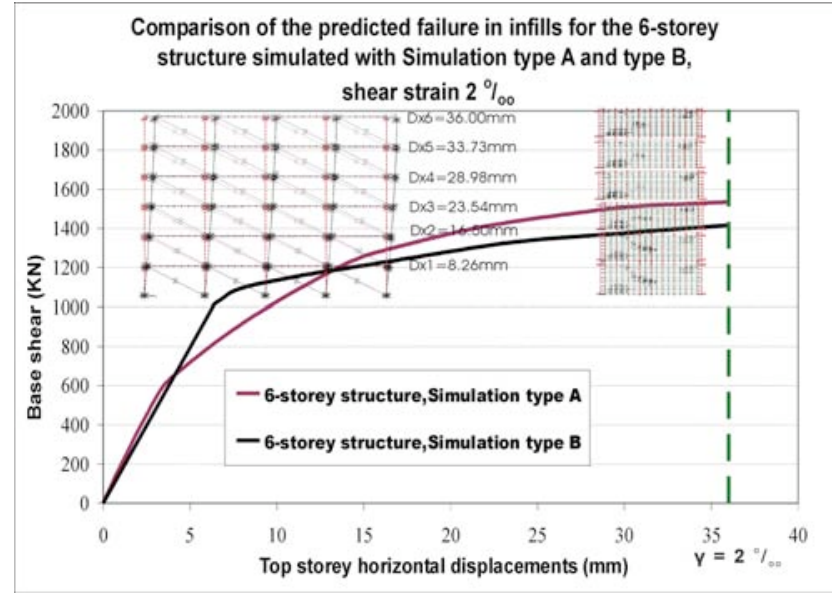

Fig. (38). Base shear - top story displacement "pushover" response

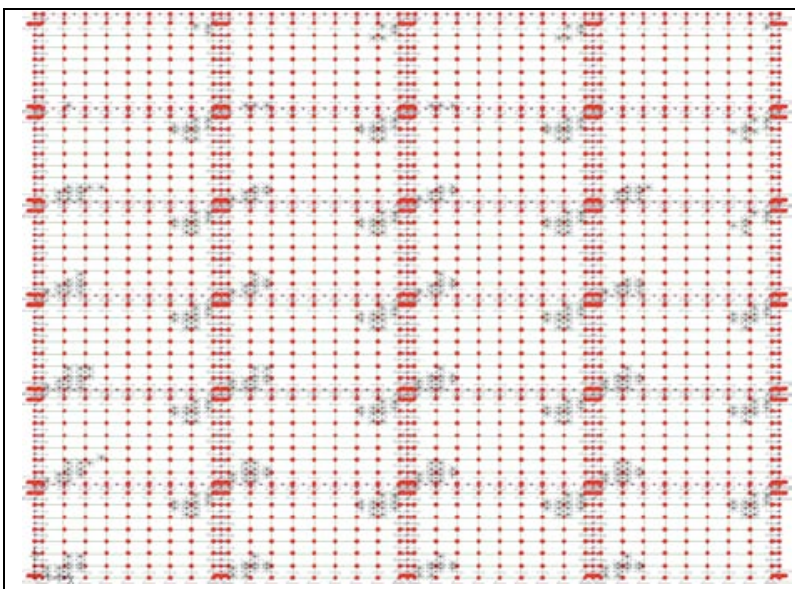

a) Masonry damage prediction type $A$

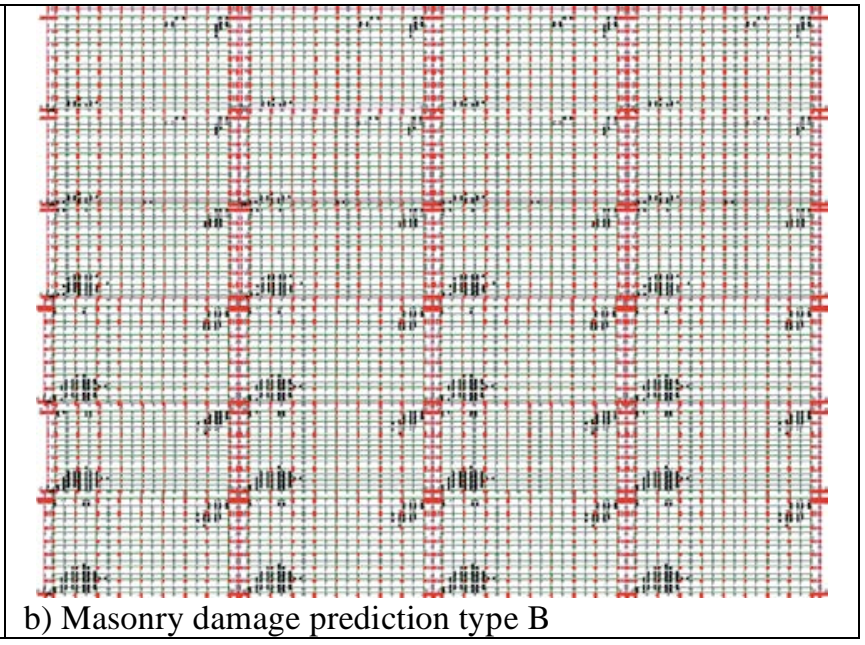

b) Masonry damage prediction type B

Fig. (37). Detail of masonry infill damage patterns, as predicted by either type A or type B simulations, for top story target displacement equal to $0.1 \%$ of the building height. 


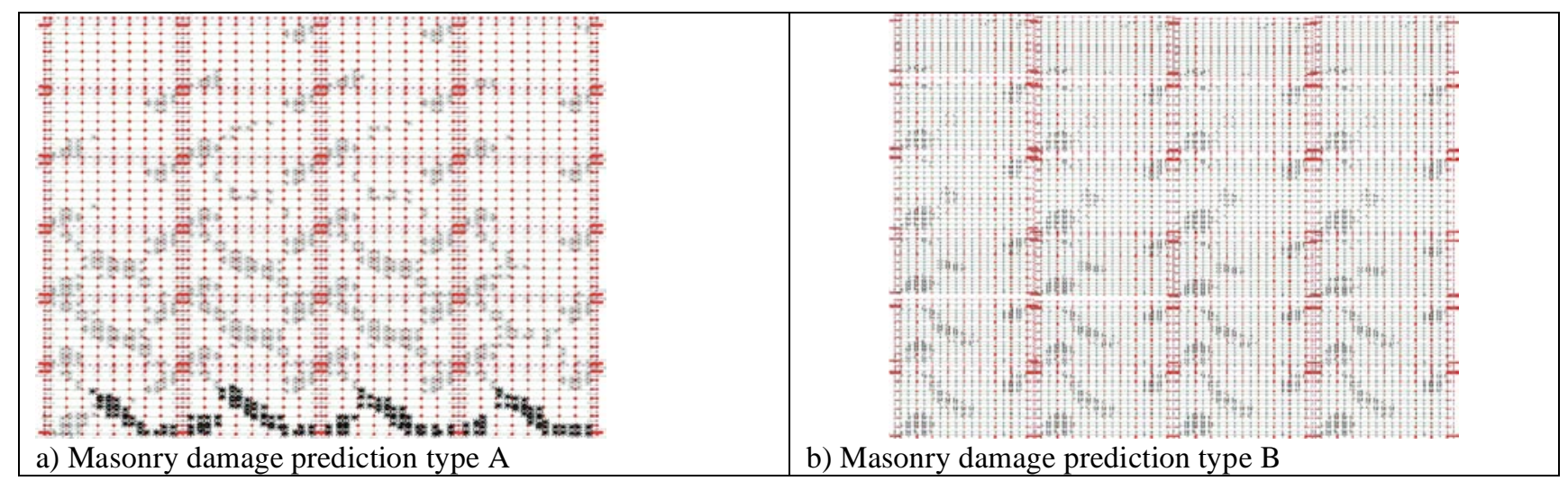

Fig. (39). Detail of masonry infill damage patterns, as predicted by either type A or type B simulations, for top story target displacement equal to $0.2 \%$ of the building height

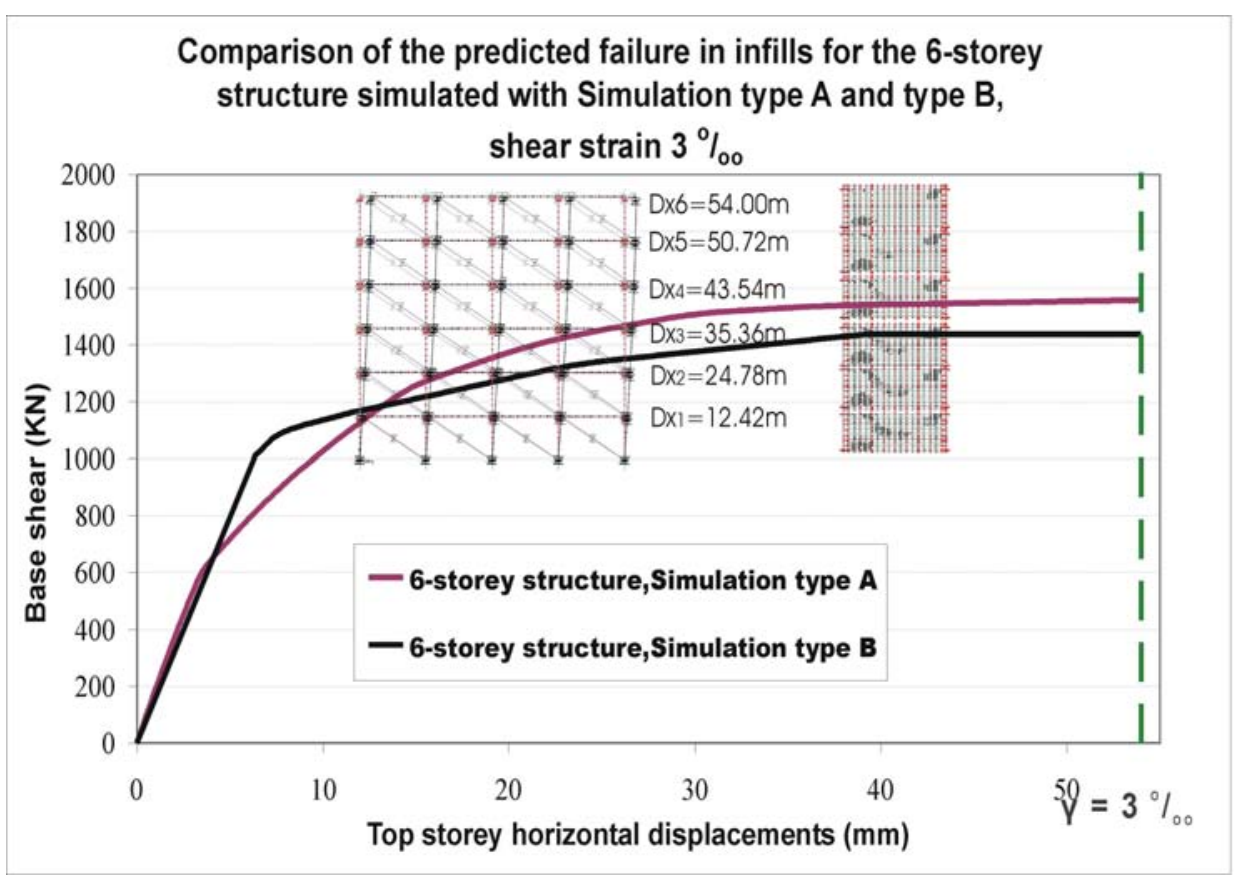

Fig. (40). Base shear - top story displacement "pushover" response as predicted by either type A or type B $(\gamma=0.3 \%)$.

as predicted by either type A or type $\mathrm{B}(\gamma=0.2 \%)$.

\section{CONCLUDING OBSERVATIONS}

The strength and load-displacement hysteretic behaviour observed during the experiments of single-story one-bay masonry-infilled $\mathrm{R} / \mathrm{C}$ frames examined in this study is successfully predicted of by the proposed numerical simulation.

The development of plastic hinges at the predetermined positions of columns and beam of the surrounding R/C frame observed during the experiments as well as the damage patterns for the masonry infill, in terms of crack propagation is also successfully predicted.

Finally, the dissipated energy during the experimental "seismic-type" cyclic-loading sequence is in good agreement with that resulting from the proposed numerical simulation.

The employed numerical simulation of masonry-infilled $\mathrm{R} / \mathrm{C}$ frames having their infill repaired with reinforced plaster, predicts successfully the observed during testing increase in stiffness, strength and energy dissipation due to this presence of the partially reinforced masonry infill.

The proposed numerical simulations of masonry infills incorporates influences arising from the interface between the masonry infill and the surrounding $\mathrm{R} / \mathrm{C}$ frame, as these are found to be important in obtaining realistic predictions of the masonry infill to frame interaction. Thus, the proposed numerical simulation seems to represent in a reasonable way the most important influences that the interface between masonry infill and the surrounding frame could exert on the cyclic behaviour of such structural assemblies in terms of stiffness, strength and modes of failure, as demonstrated from the observed behaviour.

The proposed numerical simulation can accommodate the use of an interface provided that the mechanical properties of the constituents of such an interface are known. The extreme cases that can be dealt with are either that of a fully rigid interface or that of a gap between the masonry infill and the surrounding frame. 


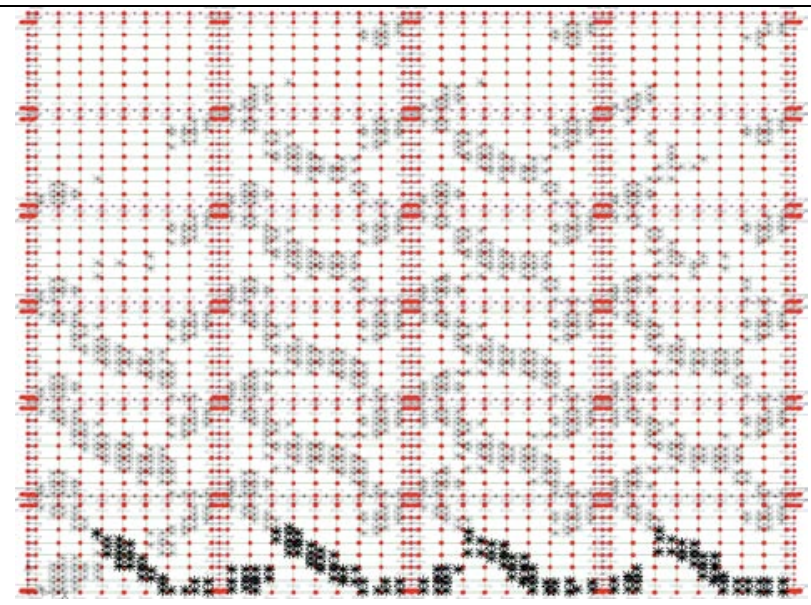

a) Masonry damage prediction type A

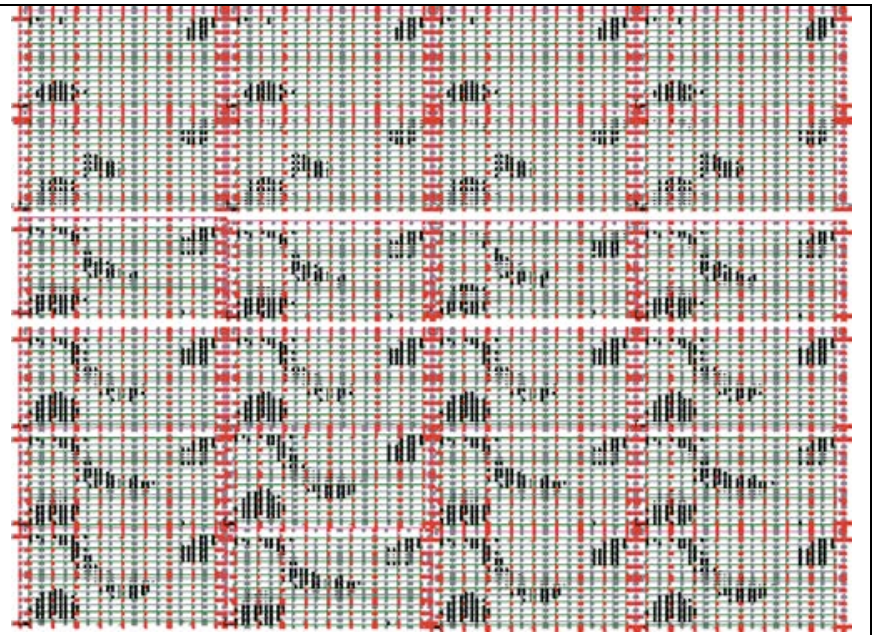

a) Masonry damage prediction type $B$

Fig. (41). Detail of masonry infill damage patterns, as predicted by either type A or type B simulations, for top story target displacement equal to $0.3 \%$ of the building height.

The damage patterns of the masonry infill observed during testing were well approximated by the proposed numerical simulation. The well known damage patterns for relatively weak "Greek" type masonry in the form of either diagonal cracking or compression failure in the regions where the masonry infill corners meet the $\mathrm{R} / \mathrm{C}$ column to beam joint, are reproduced quite well by the proposed simulation.

Based on the successful validation of the proposed numerical simulation of the non-linear response of single-story one-bay masonry-infilled $\mathrm{R} / \mathrm{C}$ frames an equivalent "pushover" analysis is proposed next for predicting the behaviour of masonry infills from their interaction with the surrounding $\mathrm{R} / \mathrm{C}$ structural elements when these masonry infills are incorporated within multi-story frame structural formations.

By comparing the response of a planar multi-story $\mathrm{R} / \mathrm{C}$ masonry-infilled frame, as predicted by the fully-nonlinear simulation type A validated in the first part of this paper and the proposed equivalent "pushover" type B analysis, it can be demonstrated that this proposed "equivalent pushover analysis" is quite successful in predicting reasonably well the "top story versus base shear" response.of this 6-story structure used for validation purposes.

By comparing the response of a planar multi-story $\mathrm{R} / \mathrm{C}$ masonry-infilled frame, as predicted by the fully-nonlinear simulation type A validated in the first part of this paper and the proposed "equivalent pushover" type B analysis, it can be demonstrated that this proposed "equivalent pushover" analysis is quite successful in predicting reasonably well the propagation of the masonry infills damage along the height of the 6-story structure used for validation purposes.

The computational time needed for this "equivalent pushover" analysis is considerably less than the computational time needed for the fully non-linear analysis of multistory masonry infilled R/C frames when all the non-linear mechanisms of structural members are included, presented in the first part of this paper. Thus, it can be used as a useful design tool in order to assess the state of masonry infills within complex multi-story structural formations. The proposed approach can also be utilized in the seismic- design for assessing the state of masonry infills and their potential damage for either newly designed or for an existing structures as part of a potential damage screening process.

It must be stressed that the proposed "equivalent pushover" analysis is an approximation. It approximates part of the non-linear bahavior and the masonry-infill to surrounding frame interaction utilizing the stiffness and strength variation of masonry infilled single-story one bay frame units that the multi-story structure is decomposed to. In this framework, given the computer time and computer memory gains that can be achieved by the proposed approximations it can be utilized in practical applications following the procedures that are generally recommended for such "pushover" type of analyses in the relevant codes of practice for earthquake design [24].

\section{CONFLICT OF INTEREST}

The authors confirm that this article content has no conflicts of interest.

\section{ACKNOWLEDGEMENT}

To the memory of Helmut Krawinkler, John A. Blume Professor Emeritus of Engineering. Stanford Scjool of Engineering, Stanford University.

\section{REFERENCES}

[1] LUSAS 13.7, Finite Element System, FEA Ltd, Kingston: UK, 2000

[2] F. da Porto, G. Guidi, E. Garbin, and C. Modena, "In-plane behavior of clay masonry walls: experimental testing and finite element modeling", ASCE, J. Struct. Eng., vol. 136, p. 1379, 2010.

[3] D. Dhanasekar, and A.W. Page, "The influence of brick masonry infill properties on the behaviour of infilled frames", Proc. Inst. Civil Eng., Part 2, vol. 81, pp. 593-605, Dec. 1986.

[4] R. Zarnic, "Modeling of Response of Masonry Infilled Frames", In: Proceedings of $10^{\text {th }}$ European Conference on Earthquake Engineering, 1995, pp. 1481-1486.

[5] R. Zarnic, J. Selih, F.B. Damjanic, and S. Gostic, "Development of Macro and F.E Models of Masonry", In: Proceedings of $3^{\text {rd }}$ Int. Symp. on Computer Methods in Structural Masonry, Lisbon, 1995, pp. 22-31. 
[6] H. Singh, D.K. Paul, and V.V. Sastry, "Inelastic dynamic response of reinforced concrete infilled frames", J. Comput. Struct., vol. 69, pp. 685-693, 1998.

[7] K. Ghosh, and A.M. Made, "Finite element analysis of infilled frame", ASCE, J. Struct. Eng., vol. 128, no. 7, pp. 881-889, 2002,

[8] J.R. Riddington, "The influence of initial gaps on infilled frame behaviour", Proc. Inst. Civil Eng., Part 2, vol. 77, pp. 295-310, 1984.

[9] L.L. Pook, and J.L. Dawe, "Effects of Interface Conditions Between a Masonry Shear Panel and Surrounding Steel Frame", In: Proceedings of 4th Canadian Masonry Symposium, University of New Brunswick Press, Fredericton, N.B.: Canada, 1986, pp. 910921.

[10] P.G. Asteris, S.T. Antoniou, D.S. Sophianopoulos, and C.Z. Chrysostomou, "Mathematical macromodeling of infilled frames: state of the art", ASCE J. Struct. Eng., vol. 137, no. 12, pp. 15081517, 2011.

[11] G.C. Manos, V.J. Soulis, and J. Thauampteh, "The behaviour of masonry assemblages and masonry-infilled R/C frames subjected to combined vertical and cyclic horizontal seismic-type loading", $J$. Adv. Eng. Softw., vol. 45, pp. 213-231, 2011.

[12] K. Stylianides, "Experimental Investigation of the Behaviour of Single-story Infilled R/C Frames under Cyclic Quasi-static Horizontal Loading (Parametric Analysis", Ph.D. Thesis, Department of Civil Engineering, Aristotle University of Thessaloniki, Greece, 1985.

[13] K. Stylianides, "Cyclic Behaviour of Infilled R/C Frames", In: Proceedings of $8^{\text {th }}$ Brick/Block Masonry Conference, vol. 2, Dublin, Ireland, 1988, pp. 792-799.

[14] P.G. Carydis, H.P. Mouzakis, J.M. Taflambas, and E.A. Vougioukas, "Response of Infilled Frames with Brickwalls to Earthquake Motions", In: Proceedings of $10^{\text {th }}$ World Conference of Earthquake Engineering, Madrid, July 1992, pp. 2829-2834.

[15] T. Valiasis, "Experimental Investigation of the Behavior of R.C. Frames Filled with Masonry Panels and Subjected to Cyclic Horizontal Load - Analytical Modelling of the Masonry Panel", Ph.D.
Thesis, Department of Civil Engineering, Aristotle University of Thessaloniki, Greece, 1989.

[16] J. Thauampteh, "Experimental Investigation of the Behaviour of Single-story R/C Frames with Masonry Infills, Virgin and Repaired, under Cyclic Horizontal Loading", Ph.D. Thesis, Department of Civil Engineering, Aristotle University of Thessaloniki, Greece, 2009.

[17] G.C. Manos, B. Yasin, M. Triamataki, and M. Demosthenous, "Experimental and Numerical Simulation of the Influence of Masonry Infills on the Seismic Response of Reinforced Concrete Frame Structures", In: Proceedings of $4^{\text {th }}$ Int. Mas. Conference of the British Masonry Society, vol. 2, no. 88, 1995, pp. 495-502.

[18] V.J. Soulis, "Investigation of the Numerical Simulation of Masonry Infilled R/C Frame Structures under Seismic-type Loading", Ph.D. Thesis, Department of Civil Engineering, Aristotle University of Thessaloniki, Greece, 2009.

[19] R.E. Klingner, and V.V. Bertero, "Infilled Frames in Earthquake Resistant Construction", EERC, Report No. 76-32, University of California, Berkeley, California, USA, Dec. 1976.

[20] M. Holmes, "Steel frames with brickwork and concrete infilling", Proc. Inst. Civil Eng., vol. 19, 1961.

[21] M. Holmes, "Combined loading on infilled frames", Proc. Inst. Civil Eng., vol. 25, 1963.

[22] B. Yasin, "Experimental Investigation of the Influence of Infills on the Dynamic Response of Building Structures Through the Study of Scaled Physical Models", Ph.D. Thesis, Department of Civil Engineering, Aristotle University of Thessaloniki, Greece, 1999.

[23] S. Mahin, and V.V. Bertero, "R.C.COLA, A Computer Program for Reinforced Concrete Column Analysis - User's Manual and Documentation", Department of Civil Engineering, University of California: Berkeley, August 1977.

[24] Eurocode, 8 Part 1 and Part 3 (EN 1998-3): European Committee for Standardization 2004.

(C) Manos et al.; Licensee Bentham Open.

This is an open access article licensed under the terms of the Creative Commons Attribution Non-Commercial License (http://creativecommons.org/licenses/by-nc/3.0/) which permits unrestricted, non-commercial use, distribution and reproduction in any medium, provided the work is properly cited. 